University of South Florida

DIGITAL COMMONS

Digital Commons @ University of

@ UNIVERSITY OF SOUTH FLORIDA

South Florida

1997

\title{
Morphology and Distribution of Seamounts Surrounding Easter Island
}

Yoav Rappaport

University of South Florida

D. F. Naar

University of South Florida, naar@usf.edu

C. C. Barton

Geological Survey, St. Petersb

Z. J. Liu

University of South Florida

R. N. Hey

University of Hawaii

Follow this and additional works at: https://digitalcommons.usf.edu/msc_facpub

Part of the Life Sciences Commons

\section{Scholar Commons Citation}

Rappaport, Yoav; Naar, D. F.; Barton, C. C.; Liu, Z. J.; and Hey, R. N., "Morphology and Distribution of Seamounts Surrounding Easter Island" (1997). Marine Science Faculty Publications. 2222.

https://digitalcommons.usf.edu/msc_facpub/2222

This Article is brought to you for free and open access by the College of Marine Science at Digital Commons @ University of South Florida. It has been accepted for inclusion in Marine Science Faculty Publications by an authorized administrator of Digital Commons @ University of South Florida. For more information, please contact digitalcommons@usf.edu. 


\title{
Morphology and distribution of seamounts surrounding Easter Island
}

\author{
Yoav Rappaport, ${ }^{1,2}$ D. F. Naar, ${ }^{1}$ C. C. Barton, ${ }^{3}$ Z. J. Liu, ${ }^{1,4}$ and R. N. Hey ${ }^{5}$
}

\begin{abstract}
We investigate the morphology and distribution of a seamount population on a section of seafloor influenced by both superfast seafloor spreading and hotspot volcanism. The population under investigation is part of a broad chain of seamounts extending eastward from the East Pacific Rise, near Easter Island. In order to define the morphological variability of the seamounts, basal shape, cross-sectional area, volume, flatness, and flank slope are plotted against height for 383 seamounts with heights greater than $200 \mathrm{~m}$, based on bathymetry data collected by GLORI-B and SeaBeam 2000, during three cruises onboard the R/V Melville in the spring of 1993. Nearly complete swath mapping coverage of the seamounts is available for the analysis of size and shape distribution. We quantitatively describe the seamount population of this active region, in which seamounts cover $\sim 27 \%$ of the seafloor, and account for $\sim 4.2 \%$ of the total crustal volume. Over $50 \%$ of the total volume $\left(61,000 \mathrm{~km}^{3}\right)$ of seamounts used in this study is made up by the 14 largest seamounts, and the remaining volume is made up by the 369 smaller seamounts ( $>200 \mathrm{~m}$ in height). Our analysis indicates there are at least two seamount populations in the Easter Island-Salas y Gomez Island $\left(25^{\circ}-29^{\circ} \mathrm{S}, 113^{\circ}-104^{\circ} \mathrm{W}\right)$ study area. One population of seamounts is composed of short seamounts $(<1200 \mathrm{~m}$ in height) with variable flatness from pointy cones to flattened domes (flatness from 0.01 to 0.57 ) and predominantly steep flanks (slopes from $5^{\circ}$ to $32^{\circ}$ ). A second population is of massive $(>1200 \mathrm{~m}$ ), shield-like, pointy cones (flatness $<0.2$ ) and gentle slopes (from $5^{\circ}$ to $15^{\circ}$ ). An exponential maximum likelihood distribution is fit to the binned raw frequency of height and gives a characteristic height of the seamount population of $308 \pm 12 \mathrm{~m}$ and an expected number of seamounts per $1000 \mathrm{~km}^{2}$ of 2.7 \pm 0.15 . Many seamounts that have different slope and flatness relationships with height are formed next to each other. We speculate that the larger volcanoes $(>\sim 1200 \mathrm{~m})$ originate exclusively from a hotspot source, but only a portion of the smaller volcanoes $(<\sim 1200 \mathrm{~m})$ are formed from a hotspot source. The remainder would be presumably formed by a normal mantle or mixed source.
\end{abstract}

\section{Introduction}

A broad chain of seamounts extends from the East Pacific Rise (EPR) eastward toward South America in the southeastern Pacific (Figure 1) in a region influenced by superfast spreading and hotspot volcanism. Here we quantitatively describe this seamount population using nearly $100 \%$ coverage of GLORI-B [Somers and Huggett, 1993] and SeaBeam 2000 bathymetry data. Analysis of the side-scan and bathymetry data, covering $243,000 \mathrm{~km}^{2}$ of seafloor, collected on the GLORIA expedition (Legs 5-7) in early 1993 [Naar et al., 1993a, b], show that seamounts in the Easter-Salas y Gomez Islands area $\left(25^{\circ}-29^{\circ} \mathrm{S}\right.$,

\footnotetext{
${ }^{1}$ Department of Marine Science, University of South Florida, St. Petersburg.

2 Now at Infrastructure Support Services, City of Austin, Austin, Texas.

${ }^{3}$ Geological Survey, St. Petersburg, Florida.

4 Now at Departments of Geophysics and Computer Science, Stanford, California.

${ }^{5}$ School of Ocean and Earth Science and Technology, University of Hawaii, Honolulu.
}

Copyright 1997 by the American Geophysical Union.

Paper number 97JB01634.

0148-0227/97/97JB-01634\$09.00 $113^{\circ}-104^{\circ} \mathrm{W}$ ) have a variability in shape and size (height and volume) distributions [Rappaport et al., 1994; Rappaport, 1996].

We examine the distribution and morphology of seamounts along the Easter Seamount Chain (ESC), in order to investigate the relationship between mantle plumes and midocean ridges in a superfast spreading environment. This study is unique because it is the first study of its kind to investigate morphology and distribution of volcanoes in both a hotspot and superfast seafloor spreading environment. The motivation for this study is to gain a better understanding about the processes at work in this unique tectonic/volcanic setting.

Our approach is to conduct a statistical study of the morphology and distribution of the seamounts [e.g., Jordan et al., 1983; Smith and Jordan, 1987, 1988, Smith, 1988]. Seamounts along the western part of the ESC are identified as discrete features whose morphological character is described quantitatively in terms of height, volume, basal radius, summit radius, cross-sectional area, flatness, and slope. This study includes seamounts with heights from $200 \mathrm{~m}$ to $3300 \mathrm{~m}$. However, we fit the seamount size distributions using the maximum likelihood binned method for volcanoes ranging from $200 \mathrm{~m}$ to $1000 \mathrm{~m}$ in order to compare with previous studies and to avoid using bins with less than five volcanoes.

We investigate if the different morphologies are formed by the same process and why is there such a broad distribution of 


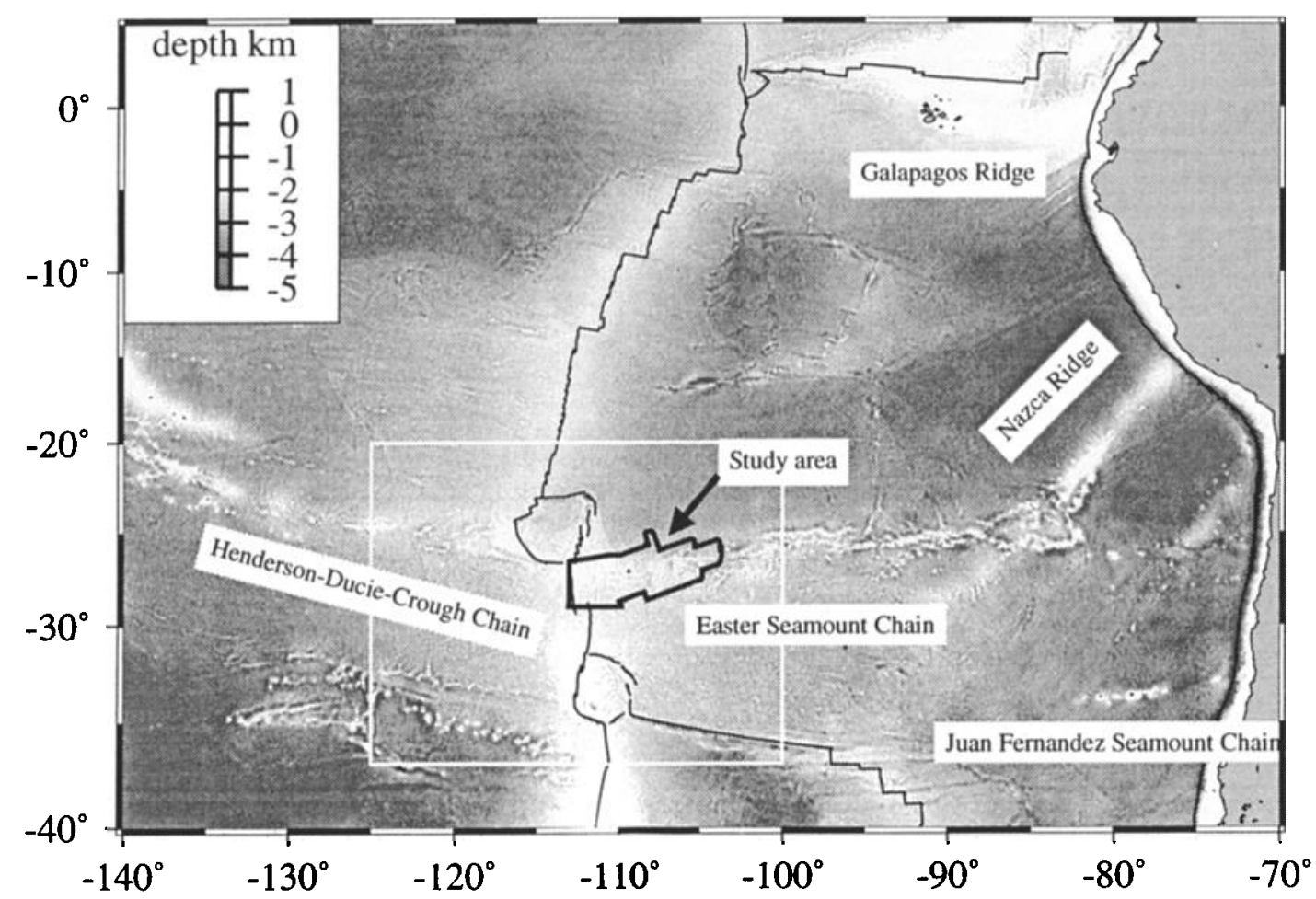

Figure 1. Location map showing southeastern Pacific predicted bathymetry. Image shows seafloor depth predicted from ETOPO5 data and free-air gravity anomalies calculated from the Geosat altimetric data [Liu, 1996]. Some major features of the southeastern Pacific are included; the thick line marks the boundary of the study area. The thin line marks plate boundaries. The white line marks boundary of region in Figure 2.

volcanism. The distribution of volcanoes is significantly different than any other area along the fast spreading EPR and different than the long and linear hotspot chains found elsewhere, suggesting that the interaction between fast seafloor spreading and hotspot volcanism may be responsible [Hagen et al., 1990; Liu, 1996]. Other studies of seamounts in the Pacific Ocean have deliberately focused on seamounts away from known hotspots [Abers et al., 1988; Batiza, 1982; Fornari et al., 1987b; Kleinrock and Brooks, 1994; Scheirer and Macdonald, 1995; Scheirer et al., 1996; Smith and Jordan, 1987]. Bemis and Smith [1993] did cover an area of hotspot volcanism over the Superswell area of the Pacific, but they did not have $\sim 100 \%$ bathymetric coverage. The only study of seamounts formed by a hotspot and near a ridge is in the slow spreading Mid-Atlantic Ridge area [Magde and Smith, 1995]. The morphology and distribution characteristic of these seamounts are common to the slow spreading ridges despite the presence of a hotspot. This is not the case in our study area which appears to be significantly affected by the presence of a hotspot.

\section{Background}

Seamount shape and size distributions are studied in order to gain a better understanding of the chemical character of the extruding magma, its availability, the nature of the plumbing system, and the character of the lithosphere [Batiza, 1989; Batiza and Vanko, 1984; Fornari et al., 1987a, 1988; Scheirer and Macdonald, 1995; Searle, 1983; Shen et al., 1993, 1995; Smith and Cann, 1992, 1993]. Based on the geometric form of seamounts, inferences may be made about the physical properties of the extruding lava viscosity, effusion rate, availability, temperature during the edifice building process [Binard et al., 1991; Fornari et al., 1987b; Macdonald et al., 1993; Magde and Smith, 1995; Scheirer and Macdonald, 1995; Scheirer et al., 1996; Smith. 1988; Vogt and Smoot, 1984], and modification by postemplacement processes [Moore et al., 1989; Smoot and King, 1992]. Primary control of shape is by (1) the tectonic setting [Batiza, 1982], (2) fracture pattern of the plate [Clark and Dymond, 1977; McNutt et al., 1989], (3) mantle heterogeneities (thermal and compositional) [e.g., Davis and Karsten, 1986; Kincaid et al., 1996], (4) age and thickness of the lithosphere [e.g., Vogt, 1974], (5) chemical composition of the magma [e.g., Batiza et al., 1989], (6) physical properties of the magma such as effusion rate and viscosity [e.g., Bonatti and Harrison, 1988], (7) shape, size, and geometric relations of magma supply conduits [Fornari et al., 1987a], (8) availability of magma, and (9) postemplacement modification such as reef growth, wave truncation, and/or slope failure [Holcomb and Searle, 1991; Moore et al., 1989; Smoot and King, 1992].

\subsection{Seamount Formation Environments}

Statistical studies of seamount populations have been conducted in a variety of tectonic regimes, including slow spreading regions of the Atlantic distant from hotspots [Smith and Cann, 1990], slow spreading regions influenced by hotspots such as Iceland [e.g., Magde and Smith, 1995], and fast spreading regions of the Pacific distant from hotspots [Abers et al., 1988; Alexander and Macdonald, 1996; Batiza, 1982; Fornari et al., 1987b; Menard, 1964; Scheirer et al., 1996; Smith and Jordan, 1987, 1988]. 
2.1.1. Slow spreading Mid-Atlantic Ridge. Seamounts are commonly associated with volcanic processes in an intraplate or near-axis setting. Near-axis seamount production is primarily controlled by spreading rate and magma flux [Alexander and Macdonald, 1996; Scheirer et al., 1996: Smith and Cann, 1993]. In slow spreading environments such as the northern Mid-Atlantic Ridge (MAR), seamounts are formed within the median valley floor and transported by large-scale faulting to the ocean floor [Magde and Smith, 1995; Smith and Cann, 1993]. The region is dominated by axial rift valleys $30-45 \mathrm{~km}$ wide and $1-2 \mathrm{~km}$ deep, with an inner valley floor bounded by normal faults that are hundreds of meters high [Macdonald, 1986]. The inner valley floor is the main site of crustal accretion, where production of volcanoes and ridges up to several hundred meters high takes place. This volcanism is proposed to originate from small pockets of melts rising through the lithosphere to the base of the asthenosphere. Melts are ponded at a brittle/ductile boundary, possibly formed by cooling via hydrothermal circulation [Chen and Morgan, 1990], or being a level of neutral buoyancy [Smith and Cann, 1993]. These models call for each edifice and flow to be fed by a separate small magma body, whose distribution is related to a distribution of magma bodies with depth [Magde and Smith, 1995; Smith and Cann, 1992, 1993; Vogt, 1974].

2.1.2. Fast spreading EPR. Scheirer et al. [1996] studied seamount abundance in the fast spreading, near-axis, zone of the southern Pacific-Nazca EPR, between $15^{\circ} \mathrm{S}$ and $19^{\circ}$ $\mathrm{S}$ (from 136 to $142 \mathrm{~mm} \mathrm{yr}^{-1}$ full rate [Hey et al., 1995]), and Scheirer and Macdonald [1995] studied seamount abundances in the northern Pacific-Nazca EPR, between $8^{\circ} \mathrm{N}$ and $17^{\circ} \mathrm{N}$ (from 84 to $118 \mathrm{~mm} \mathrm{yr}^{-1}$ full rate). Seamount production in these regions occurs within a narrow zone $5-15 \mathrm{~km}$ from the axis, with significant growth only out to $25-60 \mathrm{~km}$ from the ridge crest [Alexander and Macdonald, 1996; Macdonald et al., 1993; Scheirer and Macdonald, 1995; Scheirer et al., 1996; Shen et al., 1993]. Scheirer and Macdonald [1995] find that the greater abundance of seamounts is found on elevated and inflated regions of the northern EPR as opposed to areas with a smaller cross-sectional area. When comparing seamount abundances as a function of spreading rates and ridge morphology, Scheirer and Macdonald [1995] find that on a gross scale, near-axis seamount abundance increases with spreading rate and ridge morphology changes from a rifted valley to an axial high.

2.1.3. Intraplate volcanism. Intraplate seamount production may be found at local upwelling regions, possibly related to secondary convection rolls [Banatti et al., 1977; Richter and Parsons, 1975; Searle et al., 1995], mantle heterogeneities [Davis and Karsten, 1986; Schilling, 1985], miniplumes [Shen et al., 1993], or hotspots [Duncan and Richards, 1991; Epp, 1984; Liu, 1996; Morgan, 1972; Pilger and Handschumacher, 1981; Wilson, 1963a, b]. Hotspots may have significant interaction with a nearby ridge and lead to channeling of material [Fontignie and Schilling, 1991; Haase et al., 1996; Karsten and Delaney, 1989; Kincaid et al., 1996; Magde and Smith, 1995; Okal and Cazenave, 1985; Olson and Nam, 1986; Schilling, 1985, 1991; Schilling et al., 1985b] Points of weakness along which magma is able to penetrate the lithosphere, such as those formed by fracture zones [Clark and Dymond, 1977; McNutt et al., 1989], by diffuse regional extension [Jackson and Shaw, 1975; Sandwell et al., 1995; Searle et al., 1995; Turcotte and Oxburgh, 1978;
Winterer and Sandwell, 1987], by thermal contraction normal to spreading direction [Turcotte and Oxburgh, 1978] or by subduction zones [Sandwell et al., 1995], are favorable sites for seamount formation.

\subsection{Tectonic Setting}

The study area is a roughly rectangular region extending from the EPR to Salas y Gomez Island (SYG) between $25^{\circ} \mathrm{S}$ and $28^{\circ} \mathrm{S}$ and from $113^{\circ} \mathrm{W}$ to $104^{\circ} \mathrm{W}$, an area of roughly 243,400 $\mathrm{km}^{2}$ (Figure 1). The area lies entirely within the Nazca plate and is bounded on the west by the portion of the EPR between the Easter microplate and the Juan Fernandez microplate (Figure 2). It is part of an area of anomalously shallow topography which extends eastward to the Nazca ridge, within $\sim 1000 \mathrm{~km}$ of the coast of South America and the Peru-Chile trench. The Easter Seamount Chain (ESC) is a broad feature roughly $3000 \mathrm{~km}$ long, extending from the EPR to the Nazca ridge and trending $\sim 085^{\circ}[$ Liu, 1996]. The rate of crustal formation in this region is among to the fastest on Earth [DeMets et al., 1990; Naar and Hey, 1989]. Present-day Nazca-Pacific relative spreading (at $27^{\circ} \mathrm{S}$ ) is about $150 \mathrm{~mm} \mathrm{yr}^{-1}$ full rate [DeMets et al., 1994; Hey et al., 1995; Naar and Hey, 1989] (Figure 2). The Nazca-hotspot direction of $085^{\circ}$ that we use is calculated from the overall trend of the chain combined with the trend of the Galapagos and Juan Fernandez Islands [Liu, 1996]. Owing to lack of age data for those two chains, Liu [1996] was unable to calculate an independent rate of motion for the Nazca plate. Our absolute motion direction of the Nazca plate $\left(085^{\circ}\right)$ is different than the Gripp [1994] direction of $123^{\circ}$, because Gripp [1994] summed the Pacifichotspot vectors and the Nazca-Pacific vectors using the revised NNR-NUVEL1 global hotspot model.

Throughout the study area there are regions of young lava flows on top of older seafloor, based on interpretation of GLORI-B side-scan backscatter and magnetic anomalies [Hagen et al., 1990; Liu, 1996; Naar et al., 1993a; Stoffers et $a l ., 1994]$. The study area includes seafloor from zero age to anomaly 5 age ( 9.8 Ma) [Cande and Kent, 1995; Liu, 1996]. In detail, the volcanic construction appears complicated, but in general, several long volcanic chains dominate (Plate 1). These long off-axis volcanic ridges have trends $5^{\circ}-15^{\circ}$ oblique to relative plate motion and are aligned in a stepping pattern. The ridges are broad regions of elevated topography composed of several coalesced seamounts, $1-3 \mathrm{~km}$ in height, making chains 200-500 km long and less than $80 \mathrm{~km}$ wide [Liu, 1996]. They are separated from adjacent ridges by $50-100 \mathrm{~km}$ of lower topography and smaller volcanic edifices. Based on side-scan imagery interpretation some of the seamounts and young lava flows appear to be associated with these ridges [Liu, 1996]. However, most of the fresh volcanism, displaying high backscatter on the side-scan sonar imagery, is clearly not associated with the larger chains. This suggests that the large chains have an older origin and are not part of the younger and pervasive low-lying volcanism.

\subsection{Formation of the Easter Seamount Chain}

The chain of separate and coalesced seamounts in the study area has been identified in the literature as the Easter Fracture Zone [Clark and Dymond, 1977], the Salas y Gomez Ridge, the Easter Hot Line [Bonatti and Harrison, 1976], the Easter Volcanic Chain [Haase and Devey, 1996; Haase et al., 1996], and the Easter Seamount Chain [Liu, 1996; Naar et al., 1993a]. 


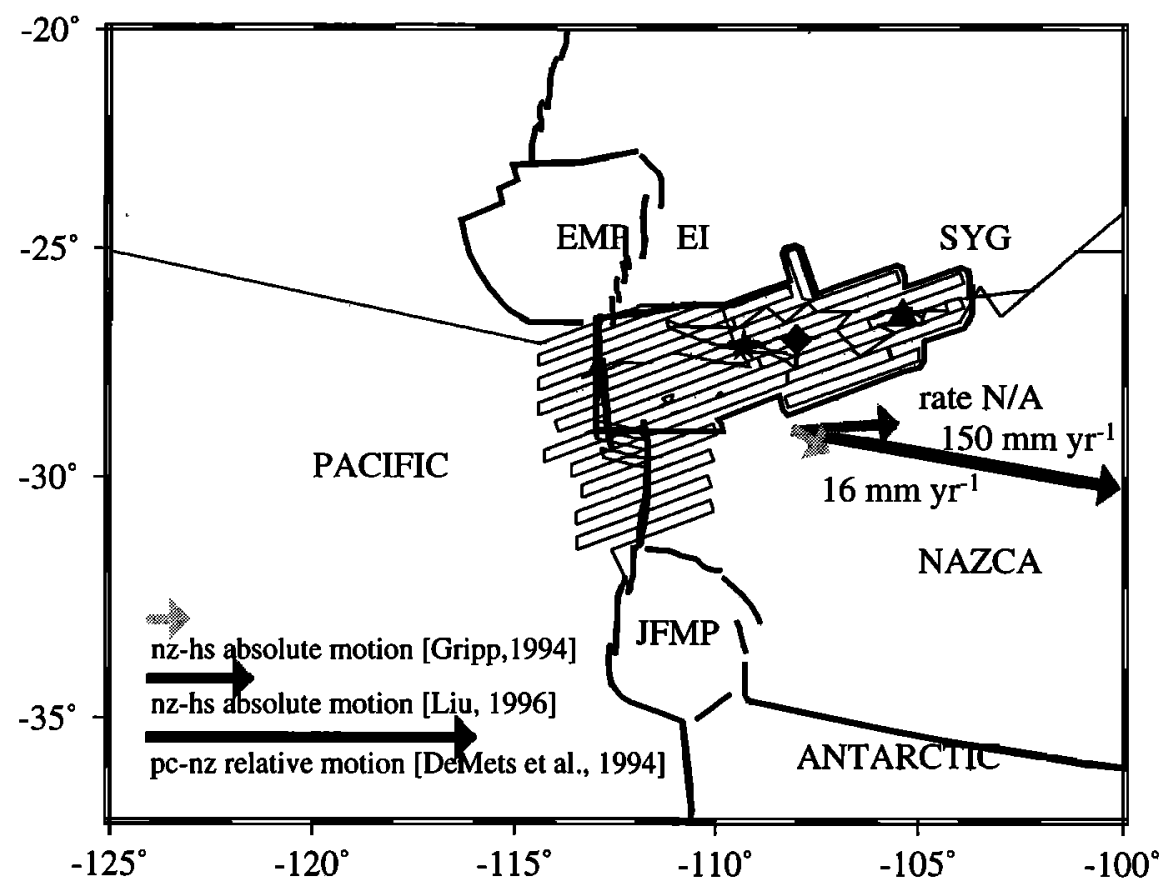

Figure 2. General tectonic setting of the study area. The boundaries of the major tectonic plates are shown by medium thick solid lines; Pacific, Nazca, Antarctic, Easter microplate (EMP), and Juan Fernandez microplate (JFMP). Easter Island (EI) and Salas y Gomez Island (SYG) locations are marked with a solid star and triangle, respectively. GLORI-B leg 5,6 and 7 cruise tracks are shown by a thin solid line, and boundary of the study area is show as a thick solid line. The Nazca-Pacific relative plate motion vector is calculated from the NUVEL-1A model at $27^{\circ} \mathrm{S}$ and $108^{\circ} \mathrm{W}$ (marked by a solid diamond), trending $100^{\circ}$, at a full rate of $150 \mathrm{~mm}$ $\mathrm{yr}^{-1}$ [DeMets et al., 1994]. Nazca-hotspot absolute plate motion direction is trending $85^{\circ}$ with an undetermined rate, based on a Nazca bestfit Euler pole to three hotspot chains [Liu, 1996] (Table 1). The Nazca-hotspot absolute plate motion vector is trending $123^{\circ}$, at a rate of $16 \mathrm{~mm} \mathrm{yr}^{-1}$ [Gripp, 1994].

The mode of formation is still under current debate, but geochemical results suggest that the volcanism is a result of a complex interaction of the lithosphere with the asthenosphere [Haase and Devey, 1996; Hanan and Schilling, 1989; Poreda et al., 1993b]. The ESC was first interpreted as a trace of lithosphere motion over a hotspot [Pilger and Handschumacher, 1981; Morgan, 1971, 1972; Wilson, 1963a]. Subsequently, new models have been proposed to explain the complex bathymetric and geochemical findings, which could not be explained by a simple hotspot model. KAr radiometric age data suggested contemporaneous volcanism along the entire length of the chain [Clark and Dymond, 1977; Bonatti et al., 1977]. This age pattern was modeled as (1) a "leaky fracture zone" [Clark and Dymond, 1977], in response to large-scale plate reorientation of the spreading centers; (2) a "hot line" [Bonatti and Harrison, 1976; Bonatti et al., 1977; Maia et al., 1994], where the ESC formed as a result of mantle activity occurring along the rising limbs of adjacent Richter secondary convective rolls [Richter and Parsons, 1975]; or (3) a "diffuse extension" [Sandwell et al., 1995; Winterer and Sandwell, 1987], where the ESC formed in response to regional extension in troughs of thinned and cracked lithosphere. Other models have been proposed including (4) a "plume-ridge interaction" [Fontignie and Schilling, 1991; Haase and Devey, 1996; Haase et al., 1996, 1993; Hanan and Schilling, 1989; Kincaid et al., 1996; O'Conner et al., 1995; Okal and Cazenave, 1985; Poreda et al, 1993b; Schilling, 1991; Schilling et al., 1985a] to explain mixing between plume and mid ocean ridge basalt (MORB) as well as a nonlinear increase of ages to the east; and (5) a "sheared plume" [lhinger, 1995; Liu, 1996], where "plumlets" of primordial mantle material rise to the base of the lithosphere, crossing a shear zone, and are stretched into "football"-shaped lenses, to explain the enechelon pattern of ridges and age data. The more recent geochronological $\mathrm{Ar}^{39} / \mathrm{Ar}^{40}$ data, geochemical data, and geophysical data primarily support model 4.

\section{Methods}

We measure seamount height, basal area, and volume and estimate slope, flatness, and cross sectional area from the gridded bathymetry. Measurements are made on side-scan and swath bathymetry data collected during GLORIA Legs 5-7, using (1) the GLORI-B $65 \mathrm{kHz}$ side-looking sonar [Somers and Huggett, 1993], and (2) the SeaBeam 2000 multibeam bathymetry and acoustic intensity imagery systems [Liu et al., 1994; 1993a; Z. Liu and D.F. Naar, Side-scan processing of GLORI-B and SeaBeam 2000, submitted to Marine Geophysical Researches, 1996, hereinafter referred to as Liu and Naar, submitted manuscript, 1996a; Z. Liu and D.F. Naar, Swath bathymetry processing of GLORI-B and SeaBeam 2000, submitted to Marine Geophysical Researches, 1996, hereinafter referred to as Liu and Naar, submitted manuscript, 1996b]. The GLORI-B system measures the phase difference and the arrival time of the returning echoes to determine the depth of the seafloor within the area insonified. To provide higher resolution the GLORI-B data were further processed and 


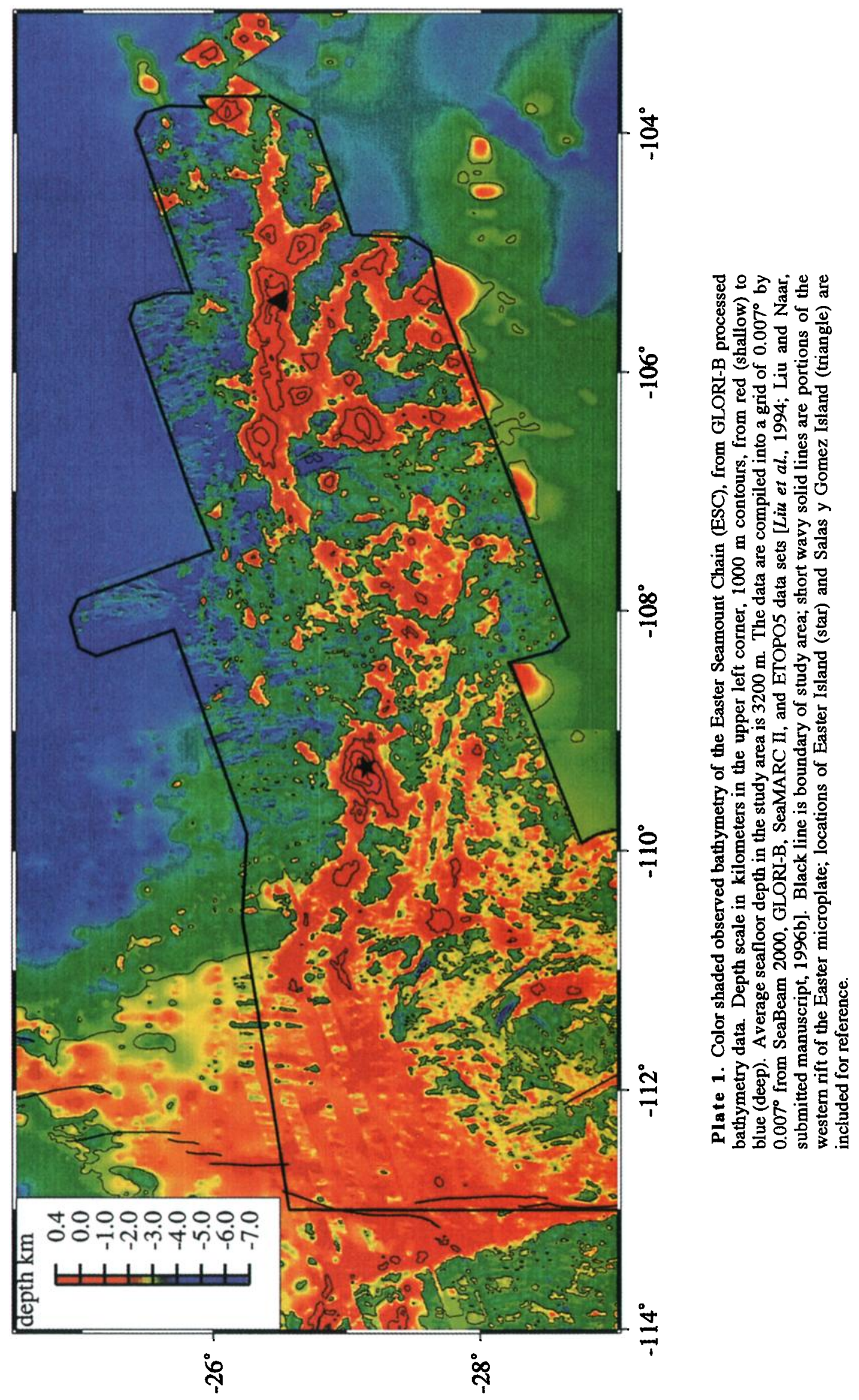


merged with SeaBeam 2000 bathymetry (Liu and Naar, submitted manuscript, 1996b) (Plate 1). The processed bathymetry is gridded at a $0.003^{\circ}(\sim 300 \mathrm{~m})$ spacing and has a vertical resolution of $\sim 50 \mathrm{~m}$ in the regions surveyed by the GLORI-B system ( 5 to $40 \mathrm{~km}$ from the track lines) and $\sim 10 \mathrm{~m}$ vertical resolution in the regions surveyed by the SeaBeam 2000 system $(\sim 5 \mathrm{~km}$ to either side of the track lines) (in Figure 2).

Only seamounts greater than $200 \mathrm{~m}$ in height and with approximately equant shapes (ratio of maximum to minimum basal diameter less than 2) are used in this study. Exclusion of seamounts with basal aspect ratio greater than 2 was done for consistency with other studies [Magde and Smith, 1995; Scheirer and Macdonald, 1995; Scheirer et al., 1996; Smith and Cann, 1992] and to reduce the possibility of including fault-controlled flows. Exclusion of seamounts with heights less than $200 \mathrm{~m}$ was necessary due to the resolution of the GLORI-B system. Individual seamounts are identified by visual inspection, and their basal outlines digitized (Figure 3). We measure height, basal area, and volume directly from the gridded bathymetry. The seamount bases are identified by inspection as a sharp break in slope from the average depth of the region (to the nearest $100 \mathrm{~m}$ contour) and by then contouring along the break in slope until each seamount is circumscribed. Seamount summits are approximated as regular ellipses, and measurements of maximum and minimum summit diameters are made by inspection of the contour plots (Figure 4). To ensure consistent method of minimum/maximum diameters for each seamount, summit diameters are not necessarily parallel to basal diameters. The height $(h)$ of the seamount is measured as the difference between the depth of its base and the shallowest point within the seamount's outline $( \pm 50 \mathrm{~m})$. In several locations, individual seamounts consist of overlapping volcanoes and volcanic ridges, making classification with these simple parameters difficult. Because the overlapping volume represents a minor component of the total volume, overlapping regions were included in the volume of both adjacent seamounts.

Previous studies approximated individual seamount edifices as regular truncated cones in order to approximate shape parameters [Bemis and Smith, 1993; Scheirer and Macdonald, 1995; Scheirer et al., 1996; Smith, 1988]. In this study we approximate seamount shapes as regular elliptical cones (Figure 4), and find that this provides a close estimation to their actual volumes and basal areas (Figure 5). Flatness $(f)$, defined as the ratio of minimum summit diameter $(d)$ to minimum basal diameter (D) $(f=d / D)$, flank slope (F= $\arctan (2 h /(D-d))$, cross-sectional area along the minimum basal diameter, and aspect ratio of minimum basal diameter to maximum basal diameter are calculated based on the approximation of seamount bases and summits as right circular ellipses (Table 1).

Many studies of seamount size distributions in the Pacific Ocean describe seamount populations as following an exponential size distribution but exclude the "large-size" fraction because of the low number of seamounts in the largest sized bins [Abers et al., 1988; Bemis and Smith, 1993; Scheirer et al., 1996; Smith and Jordan, 1987, 1988]. Following the methods of previous studies, the height of each seamount is ranked and then heights are binned into $100 \mathrm{~m}$ bins, discarding bins containing less than five counts.

\section{Results}

Over 3000 volcanoes or circular volcanic structures are identified in the GLORI-B side-scan sonar data [Liu et al., 1993; Rappaport et al., 1994]. Of these, 383 seamounts are in the height range of 200 to $3300 \mathrm{~m}$ (aspect ratio < 2), including 60 with heights greater than $1000 \mathrm{~m}$ (which is the original classic definition of a seamount by Menard [1964]). Over

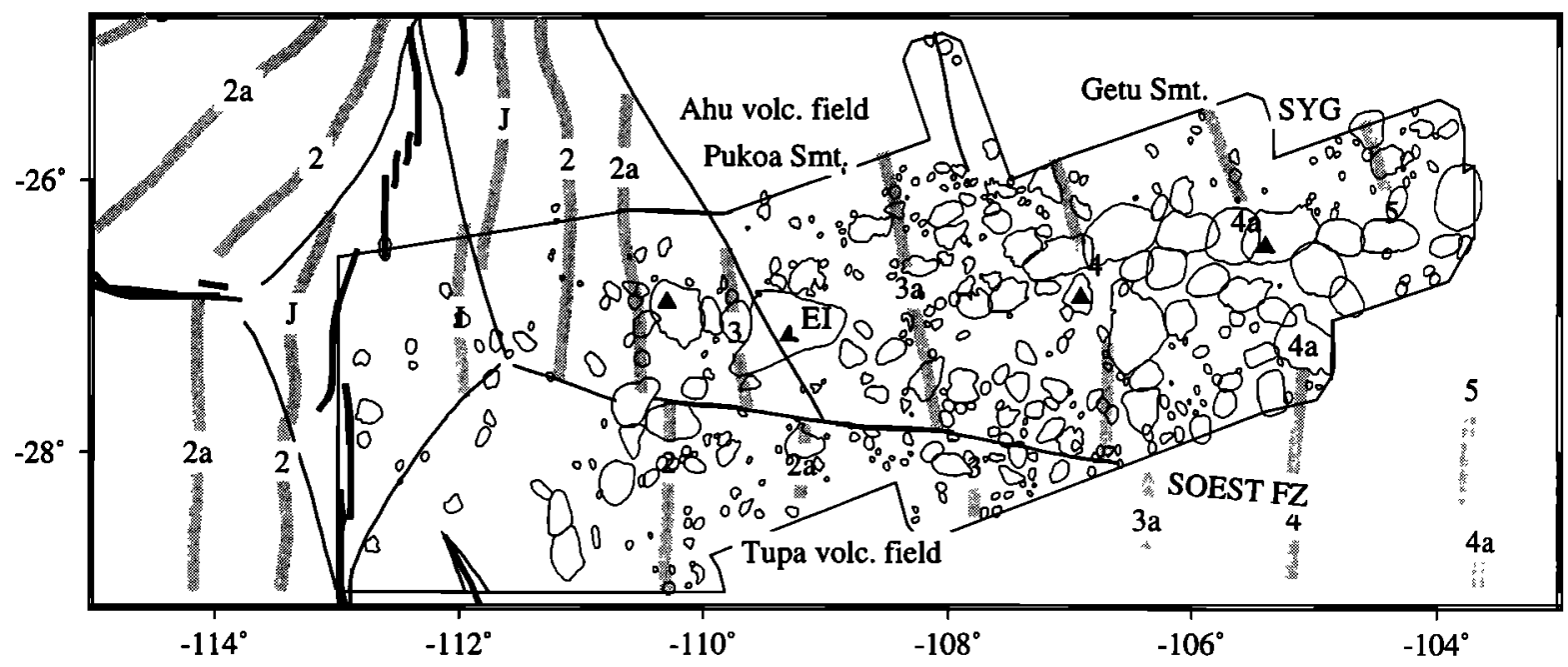

Figure 3. Basal outlines of 553 seamount used in this study, digitized from the processed gridded bathymetry data. These outlines are used to measure maximum height, basal area, and total volume from the $0.003^{\circ}$ by $0.003^{\circ}$ gridded data set. The location of Easter Island (star), Salas y Gomez Island (triangle), the ridge axis (solid line) and the study area boundary (thick solid line) are shown for reference. Gray stippled lines are age isochrons along with their magnetic anomaly designation. Spreading axis, failed propagators, fractures zone (FZ), and pseudofaults are represented by thin solid lines. Isochrons and flows are based on work by Liu [1996]. Named volcanic features are included, based on published works [Danobeitia et al., 1995; Hagen et al., 1990; Stoffers et al., 1994]. Abbreviations are: volc, volcanic; Smt, seamount; SYG, Salas y Gomez; EI, Easter Island; Isl, Island; SOEST, School of Ocean and Earth Science and Technology. 


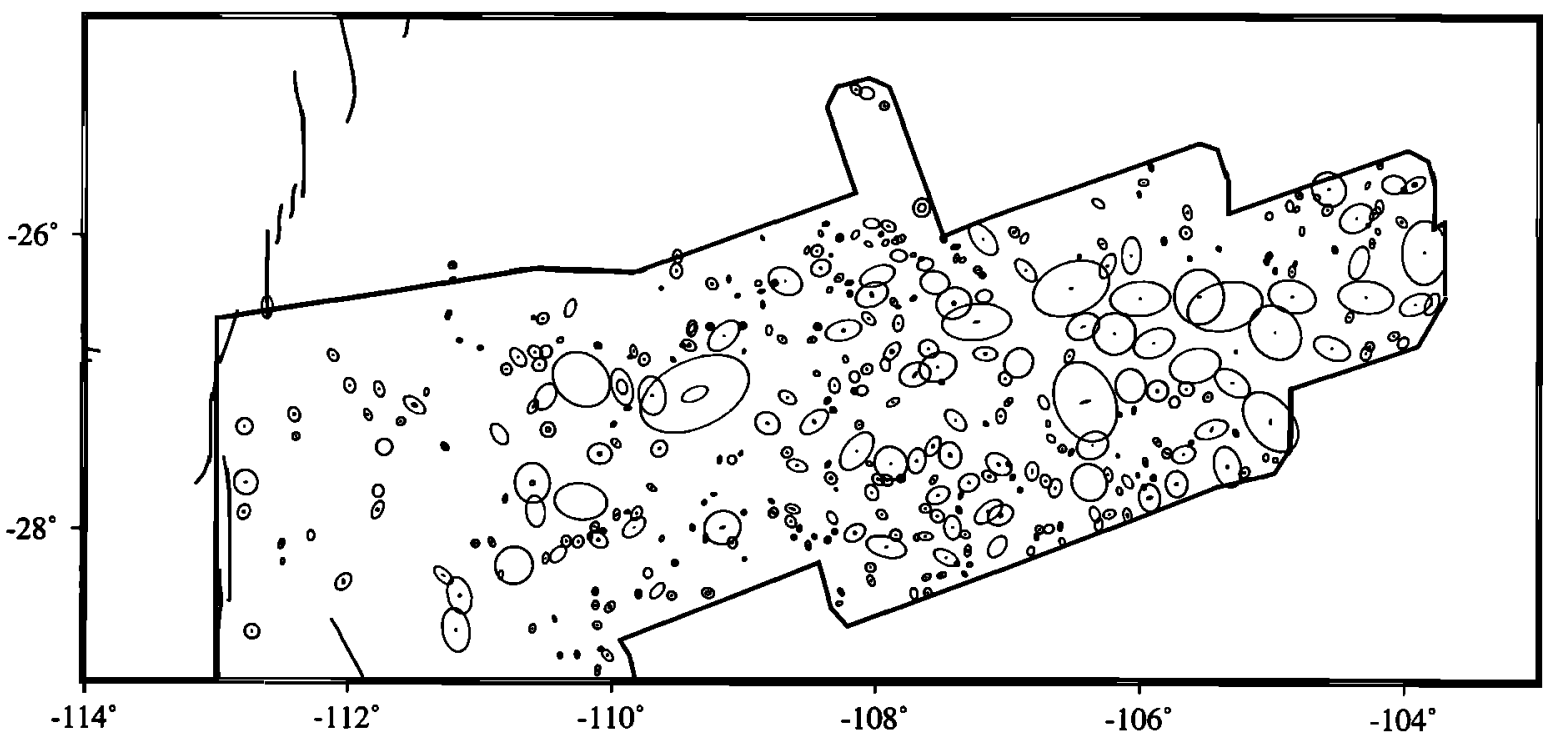

Figure 4. Elliptical approximation of digitized bases and summits of seamounts with heights $>200 \mathrm{~m}$, and aspect ratio $<2$. Ellipses are defined by the long and short axis of the bases and summits. The centers of the basal ellipses are defined by visual inspection of the center of each digitized base (Figure 3). Ellipses were drawn assuming that the long and short axis intersect at the center. This causes overlap among the idealized elliptical based seamounts but has no impact on calculation of seamount slope or flatness.

$50 \%$ of the total volume $\left(61,000 \mathrm{~km}^{3}\right)$ of seamounts used in this study is made up by the 14 largest seamounts (each with a volume $>1200 \mathrm{~km}^{3}$ ). Assuming a uniform crustal thickness of $6 \mathrm{~km}$ [Chen, 1992], the total volume represents $4.2 \%$ of the total crustal volume over the $243,00 \mathrm{~km}^{2}$ study area. The seamount basal areas cover $67,000 \mathrm{~km}^{2}$, or $27 \%$ of the seafloor. This is far greater than comparable values derived from seamounts in the near axial zone of the N-EPR $\left(8^{\circ} \mathrm{N}\right.$ $17^{\circ} \mathrm{N}$ ): $\sim 0.3 \%$ of volume and $\sim 6 \%$ of area [Scheirer and Macdonald, 1995], as expected for an area influenced by hotspot volcanism.

\subsection{Shape Distribution}

To evaluate seamount shape variability, statistics have been compiled for the 383 individual seamounts used in this study (Table 1). In Figure 6, height is plotted against six other parameters: basal radius, summit radius, volume, crosssectional area, flatness, and slope.

4.1.1. Radius. Seamount height increases with minimum basal radius as expected (Figure 6 a). The population mean of $h / r_{\min }$ is $0.25 \pm 0.01$, consistent with the value of 0.21 derived by Smith [1988] and others [Abers et al., 1988; Scheirer and Macdonald, 1995; Scheirer et al., 1996]. By contrast, no correlation appears to exist between height and summit radius (Figure $6 \mathrm{~b}$ ). The sample mean of the ratio of $h / r_{\mathrm{S}}$ is 1.74 with a standard deviation of 2.18 .

4.1.2. Volume. Volume and height were measured separately from the gridded bathymetry and thus were tabulated independently of each other. A general increase in volume with increasing height is observed, as expected (Figure 6c).

4.1.3. Cross-sectional area. The cross-sectional area of each seamount is approximated as a trapezoid, using the minimum basal diameter as the base, the minimum summit diameter as the top, and a calculated height from the base to its truncated summit (which may not be the maximum height for flattened shapes). Although the minimum summit and basal diameters are not necessarily parallel to each other, our approach provides a consistent measure of minimum diameters, and greatly reduces the influence of overlapping seamounts. A nonlinear increase in cross-sectional area with increasing height is observed (Figure 6d).

4.1.4. Flatness and slope. Flatness (the ratio of minimum summit diameter to minimum basal diameter) is plotted against height in Figure 6e. The flatness varies from 0.01 (a pointy cone) to 0.57 (a flattened truncated cone). The mean flatness is 0.14 with a standard deviation of 0.10 . Seamounts in the lower size ranges (200 to $1200 \mathrm{~m}$ ) show a much greater variability in flatness (from $\sim 0.01$ to 0.57 ) than larger ones and have corresponding flank slopes ranging between $5^{\circ}$ and $32^{\circ}$ (Figure 61 ): a mixture of pointy and flat (pancake-like) cross-sectional profiles. The largest seamounts $(>\sim 1200 \mathrm{~m})$ can be described uniformly as pointy cones (with the exception of Easter Island, where its summit plateau is taken at sea level, and thus its flatness is overestimated), with a mean flatness of 0.03 with a standard deviation of 0.02 . The typical shape of seamounts with heights greater than $1200 \mathrm{~m}$ is a pointy cone (flatness 0.2 or less), with a broad base, and slopes between $5^{\circ}$ and $15^{\circ}$. This may account for the nonlinear increase in cross-sectional area with height (Figure 6d). A relationship between slope and flatness is less clear. There is a variability of seamount slopes at all flatness ranges; however, pointy seamounts have low slopes, and flattened seamounts have highly variable flank slopes.

\subsection{Size Distribution}

We use the same methods as previous studies which have described variations in seamount size distribution and overall abundance in different tectonic environments [Abers et al., 1988; Batiza, 1982; Batiza et al., 1989; Bemis and Smith, 1993; Fornari et al., 1987b; Kleinrock and Brooks, 1994; Magde and Smith, 1995; Scheirer and Macdonald, 1995; 


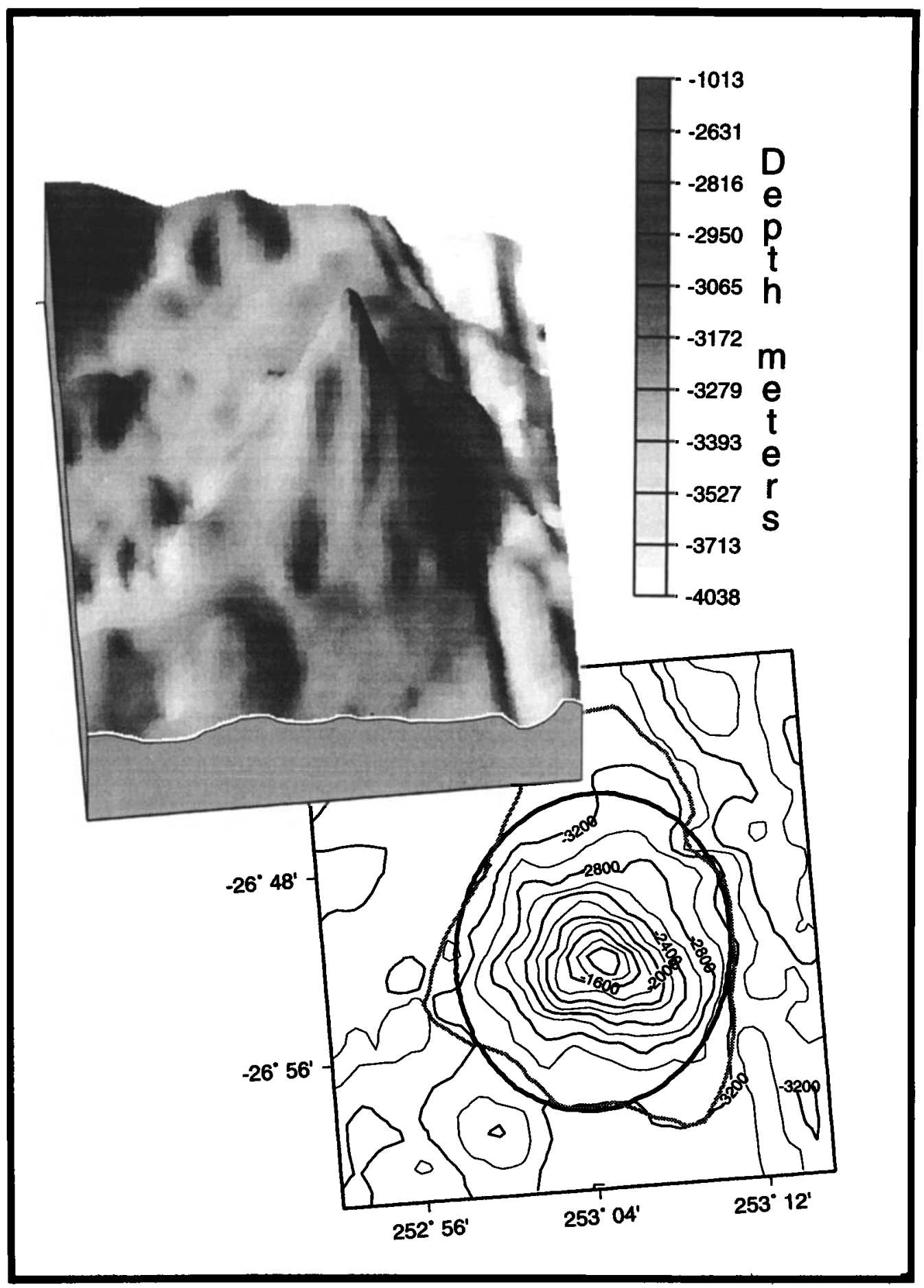

Figure 5. (Top) Shaded relief bathymetry view of Getu Seamount looking from the SSW. Illumination from the west. (Bottom) Contour map of same area with $200 \mathrm{~m}$ contours. The thick solid line is the approximation of the base as an ellipse, the thinner gray line is the basal outline, as used in the basal area and seamount volume extraction routine. This seamount is $2417 \mathrm{~m}$ high and $400 \mathrm{~km}^{3}$ in volume and has a flatness of 0.02 and a slope of $12^{\circ}$.

Scheirer et al., 1996; Smith and Cann, 1993; Smith and Jordan, 1987, 1988]. To quantify the height distribution of seamounts, Jordan et al. [1983] and subsequent studies [Abers et al., 1988; Batiza, 1982; Bemis and Smith, 1993; Kleinrock and Brooks, 1994; Scheirer et al., 1996; Smith and Jordan, 1987,1988 ] consider the cumulative frequency of seamount heights. They fit their data with a negative exponential distribution expressed as $v(H)=v_{0} \exp (-B H)$, where $v(H)$ is the number of seamounts per unit area having height greater than $H, v_{0}$ is the total number of seamounts per unit area, and $\beta$ is the negative of the slope of the line fitting $\ln (v(H))$ versus $H$, where individual seamount counts are grouped into size bins. 
Table 1. Statistical Summary of 383 Seamounts

\begin{tabular}{|c|c|c|c|c|c|c|c|}
\hline & $\begin{array}{c}\text { Height, }^{a} \\
\text { m }\end{array}$ & $\begin{array}{c}\text { Basal Area, } \\
\mathbf{k m}^{2}\end{array}$ & $\begin{array}{c}\text { Slope, }^{d} \\
\text { deg }\end{array}$ & Flatness $^{d}$ & $\begin{array}{c}\text { Volume }^{\mathrm{c}} \\
\mathrm{km}^{3}\end{array}$ & $\begin{array}{c}\text { Cross- } \\
\text { sectional } \\
\text { Area, } \\
\text { km }^{2}\end{array}$ & $h / r_{\text {man }}$ \\
\hline Mean & 640 & 174.6 & 7.6 & 0.13 & 160 & 7.3 & 0.25 \\
\hline s. d. & 540 & 378.9 & 3.8 & 0.10 & 480 & 15.9 & 0.01 \\
\hline $\begin{array}{l}\text { Minimum } \\
\text { value }\end{array}$ & 200 & 4.6 & 1.7 & 0.01 & 1 & 0.3 & 0.06 \\
\hline $\begin{array}{l}\text { Maximum } \\
\text { value }\end{array}$ & 3300 & 3757.4 & 32.0 & 0.57 & 5340 & 31.8 & 0.61 \\
\hline
\end{tabular}

The negative reciprocal of $\beta$ yields a characteristic height of the seamount sample (Figure 7).

4.2.1. Maximum likelihood fit. The model employed by Smith and Jordan [1987, 1988] uses a maximum likelihood regression fit to the raw binned frequency height data, over a set height range, and excludes bins that contain less than five seamount counts. The maximum likelihood fit requires that the seamount counts be binned, and downweights bins containing fewer counts; in this case, the highest seamounts. We follow their methodology using $100 \mathrm{~m}$ height bins and discarding bins containing less than 5 counts (Figure 7), which leaves only seamounts between 200 and $1000 \mathrm{~m}$ in height. The exponential regression to the binned data yields $\mathrm{B}^{-1}=308 \pm 12 \mathrm{~m}$, and $v_{0}=2.7 \pm 0.15$ seamounts per $1000 \mathrm{~km}^{2}$.

\section{Discussion}

\subsection{Implications of the Shape Analysis With Respect to Height}

There is no clear pattern of seamount spatial distribution in the study area. In general, seamounts are coalesced into several broad chains [Liu, 1996], but in detail they are distributed sporadically, with respect to both height and morphology (Figure 3). One population of seamounts is composed of short seamounts $(<1200 \mathrm{~m})$ with variable flatness from pointy cones (flatness of 0.01 ) to flattened domes (flatness of 0.6 ) and predominantly steep flanks (slopes of $5^{\circ}$ to $27^{\circ}$ ). A second population is of massive (height $>1200 \mathrm{~m}$ ), shield-like, pointy seamounts (flatness < 0.1 ) with gentle slopes $\left(5^{\circ}\right.$ to $\left.15^{\circ}\right)$. The smaller volcanoes may form by nonplume processes, on-or off-axis [Batiza, 1989]. In many cases, volcanoes may not have reached their maximum height because lateral conduits have opened which allowed flank eruptions. The second population is similar to those described by Batiza [1982] and Batiza et al. [1989] as formed by a plume source. The general criteria for identification of volcanoes resulting from a plume source are large size, increased geochemical isotope ratios and/or linear age progression (as seen from preliminary geochronological resuits, [Haase and Devey, 1996; O'Conner et al., 1995; R.
Duncan, personal communication, 1996]. However, control of magma volume, presence of fractures, loss of heat during ascent, and other factors influencing the distribution and abundance of seamounts make determination about the source of the magma difficult and uncertain, without further geochemical results.

The flatness and flank slope (Figures $5 e$ and Figure $5 f$ ) do not have an obvious relationship with height. Seamounts less than $1200 \mathrm{~m}$ appear to have greater variability of slope and flatness and apparently less variability with height greater than $1200 \mathrm{~m}$. This may be due in part to the smaller number of larger seamounts, or it may suggest larger volcanoes will grow laterally once they reach a certain height [Vogt, 1974]. Smith and Jordan [1987] argue that in a simple dynamical model for volcano formation, height is proportional to the hydraulic head due to the buoyancy of the magma. This assumption, first made by Vogt [1974], implies that (1) volcano size is not limited by the availability of magma so that the equilibrium height is always attained and (2) the hydraulic head is proportional to the source depth. Thus an exponential seamount height distribution could result from an exponential distribution of discrete source depths. The principal conclusion of Vogt's study was that volcano height is primarily limited by the thickness of the lithosphere at the time that the volcano is built; thus larger seamounts are able to be supported by increasing plate thickness. Although the relationship between depth of source and volcano height is observed elsewhere, it may not be solely a result of hydraulic head. Other factors controlling seamount growth include total magma supply and duration of volcano growth [Wilson et al., 1992].

\subsection{Comparison With Seamounts From Other Tectonic Environments}

The characteristic height of the population and the number of expected seamounts per unit area results are compatible with other seamount studies listed in Table 2 [Abers et al., 1988; Batiza, 1982; Bemis and Smith, 1993; Kleinrock and Brooks, 1994; Magde and Smith, 1995; Scheirer et al., 1996; Scheirer and Macdonald, 1995; Smith and Cann, 1990, 1992; Smith 

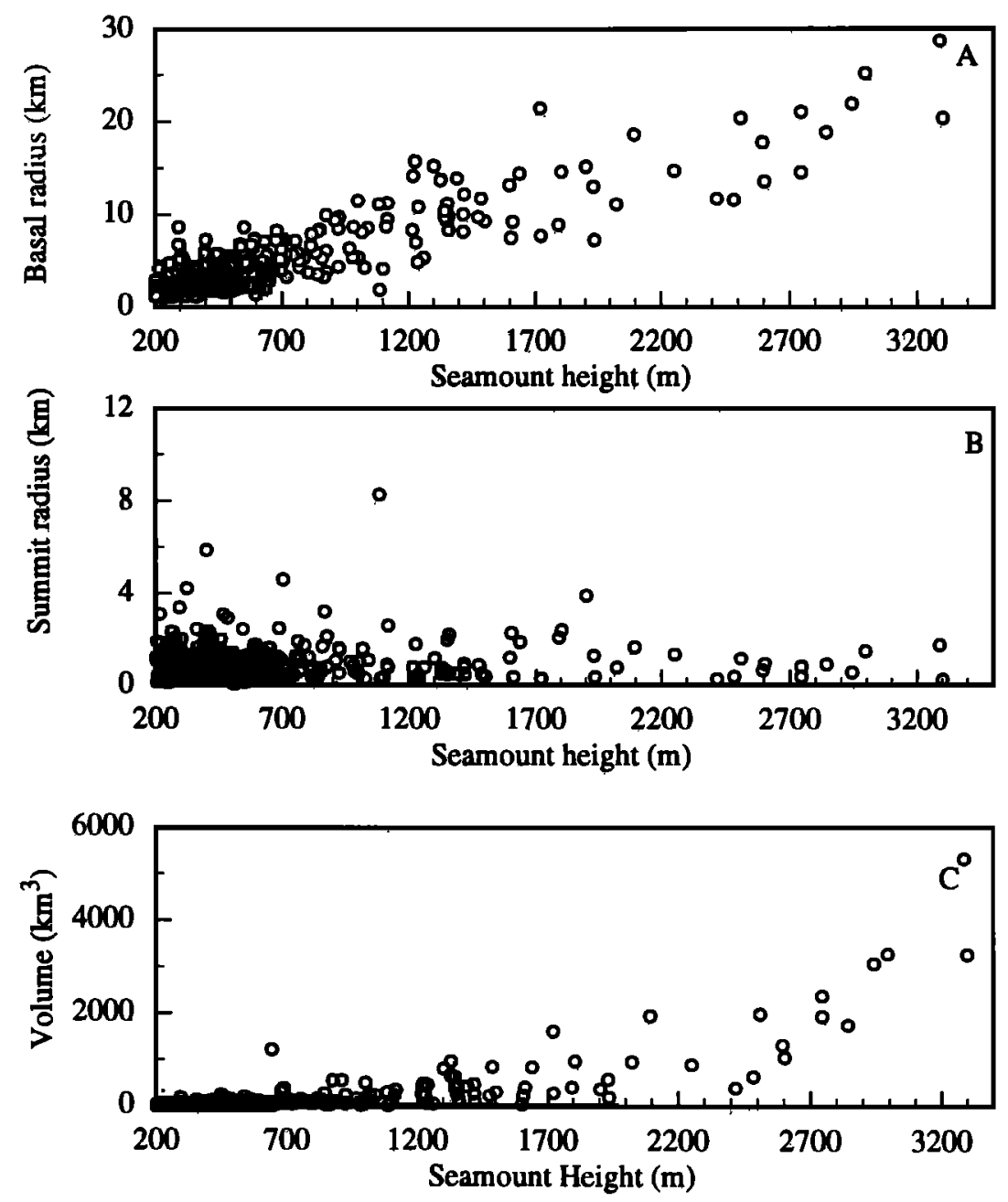

Figure 6. Cross correlation between six seamount shape properties and seamount height. There are 383 circles in each plot, representing seamounts with heights greater than $200 \mathrm{~m}$ and aspect ratio less than 2 (see text). The resolution error for all parameters is smaller than the symbol size presented. (a) Basal radius (see text) plotted against seamount height. The average ratio of $h / r_{\min }$ is $0.25 \pm 0.01$ (see Table 1). (b) Summit radius (see text) plotted against seamount height. There is no apparent relationship between the height and summit radius. (c) Volume plotted against seamount he1ght. (d) Cross-sectional area plotted against seamount height. (e) Flatness plotted against seamount height. A value of 0 is a pointy cone, and a value above 0.2 is considered a flattened-dome. Notice high variability in flatness for seamounts with heights less than $1200 \mathrm{~m}$. (f) Slope plotted against seamount height. Notice high variability in slope for seamounts with heights less than $1200 \mathrm{~m}$.

and Jordan, 1987, 1988]. The relationship between spreading rate and seamount formation is not fully understood. In general, the characteristic height of the seamounts increase and the number per unit area decrease with increasing spreading rate. One exception are results from the Galapagos where the characteristic height is found to be actually lower than that found in spreading rates more than twice as slow! The investigators suggest that this could be due to the dominance of fissure-fed flows over point sources, or another cause related to ridge propagation over older crust [Kleinrock and Brooks, 1994]. Seamounts in the slow spreading MAR are smaller and 100 times more numerous at the lower height range. The resolution of our GLORI-B data does not allow accurate identification of features smaller than $200 \mathrm{~m}$ in height. In addition, features such as abyssal hills, fault scarps, relic ridge-crest structures, and other rugged topography often have heights at $\sim 100 \mathrm{~m}$ which tend to make the identification of volcanic edifices difficult around this height [Abers et al., 1988]. Thus we cannot make a comparison with seamount distributions from slow spreading regions (height range $50-250 \mathrm{~m}$ ) [Magde and Smith, 1995, Smith and Cann, 1990, 1992].

Comparison with results from some Pacific seamount studies (Table 2) is limited because Abers et al. [1988], Bemis and Smith [1993], and Smith and Jordan [1987, 1988] describe a seamount population based on single line of wide-beam echo-sounding data and use a technique which estimates the total abundance of seamounts. Furthermore, Smith and Jordan [1987, 1988] restricted their analysis to "normal" seafloor, avoiding areas of hotspot volcanism and fracture zones. The area which we are describing is in the middle of known hotspot volcanism [Fontignie and Schilling, 1991; Haase and Devey, 1996; Haase et al., 1996, 1993; Hanan and Schilling, 1989; Kincaid et al., 1996; Liu, 1996; Morgan, 1971, 1972; 

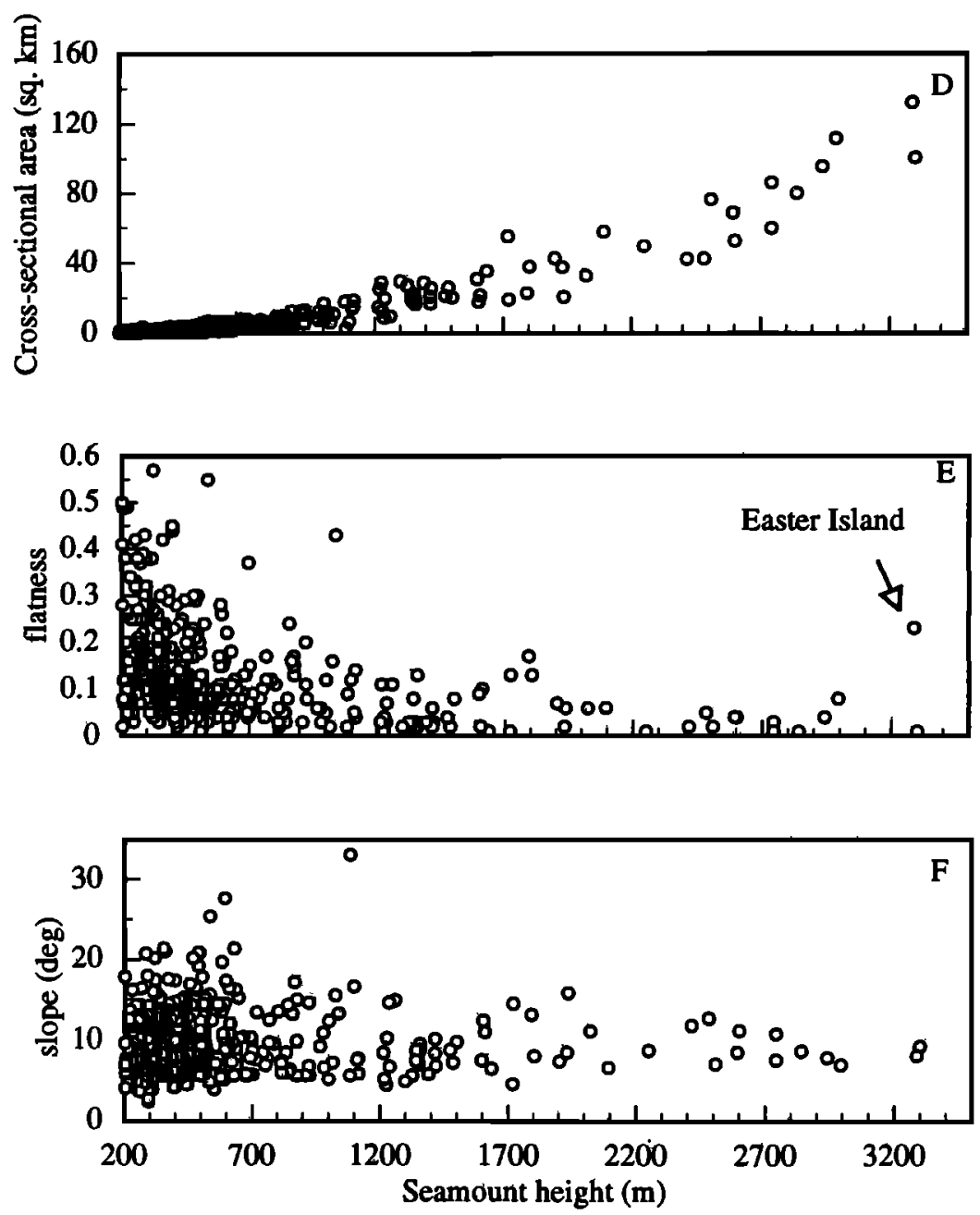

Figure 6. (continued)

O'Conner et al., 1995; Okal and Cazenave, 1985; Pilger and Handschumacher, 1981; Poreda et al., 1993b; Schilling, 1991; Schilling et al., 1985a; Wilson, 1963a].

We have $\sim 100 \%$ bathymetric coverage and do not require estimation of the large seamount population. Studies by Scheirer et al. [1996], Scheirer and Macdonald [1995], and Kleinrock and Brooks [1994] also have $\sim 100 \%$ coverage and do not rely on estimation of seamount abundances. Thus these studies can are most similar to ours. In this study the $\beta^{-1}=$ $308 \pm 12 \mathrm{~m}$ and $v_{0}=2.7 \pm 0.15$ seamounts per $1000 \mathrm{~km}^{2}$ are most similar to results obtained from seamounts in the southern EPR [Scheirer et al., 1996], also using 100\% bathymetry coverage. Scheirer et al. [1996] used a slightly greater seamount height range (200 to $1200 \mathrm{~m}$ ) than our range (200 to $1000 \mathrm{~m}$ ), which increases the $B^{-1}$ value. Mean flatness and slope ranges for the seamount population having heights between 200 and $1000 \mathrm{~m}$ overlap with studies made by Scheirer et al. [1996] and Scheirer and Macdonald [1995] having similar height ranges $(200$ to $1200 \mathrm{~m})$. Mean flatness (0.05) calculated from data provided by Scheirer et al. [1996] is significantly lower than ours, perhaps the result of the influence of hotspot material in our study area creating flatter morphologies. The mean flatness result of Bemis and Smith [1993], collected on young crust close to the EPR, is most similar to that of the Easter Island seamounts (mean flatness is $0.15 \pm 0.1)$. Our mean slope $\left(10^{\circ} \pm 9\right)$ is comparable to other Pacific seamounts studies, most closely to the $\left(13^{\circ} \pm 5.3\right)$ result of Scheirer et al. [1996]. Mean slope and flatness for the seamount population below $1000 \mathrm{~m}$ appear to be independent of hotspot volcanism because they compare well with other studies which avoid hotspot volcanism. This suggests that the volcanoes in our study area that are greater than $\sim 1000 \mathrm{~m}$ in height are primarily a result of hotspot volcanism.

\subsection{Implications for the Formation of the Easter Seamount Chain}

The morphology and distribution of the Easter seamount population suggest it was formed by more that one process, in agreement with recent work [Haase and Devey, 1996; Haase et al., 1996, 1993; O'Conner et al., 1995; Stoffers et al., 1994] It is observed from side-scan intensity and radiometric ${ }^{40} \mathrm{Ar} /{ }^{39} \mathrm{Ar}$ age data $\left[\mathrm{Liu}, 1996 ; O^{\prime}\right.$ Conner et al., 1995; R. Duncan, personal communication, 1996], that volcanism is not contemporaneous along the entire length of the chain. However, young volcanoes do exist next to older ones, especially along the western portion of the chain. Large seamount edifices (>1200 m) are only found on seafloor 


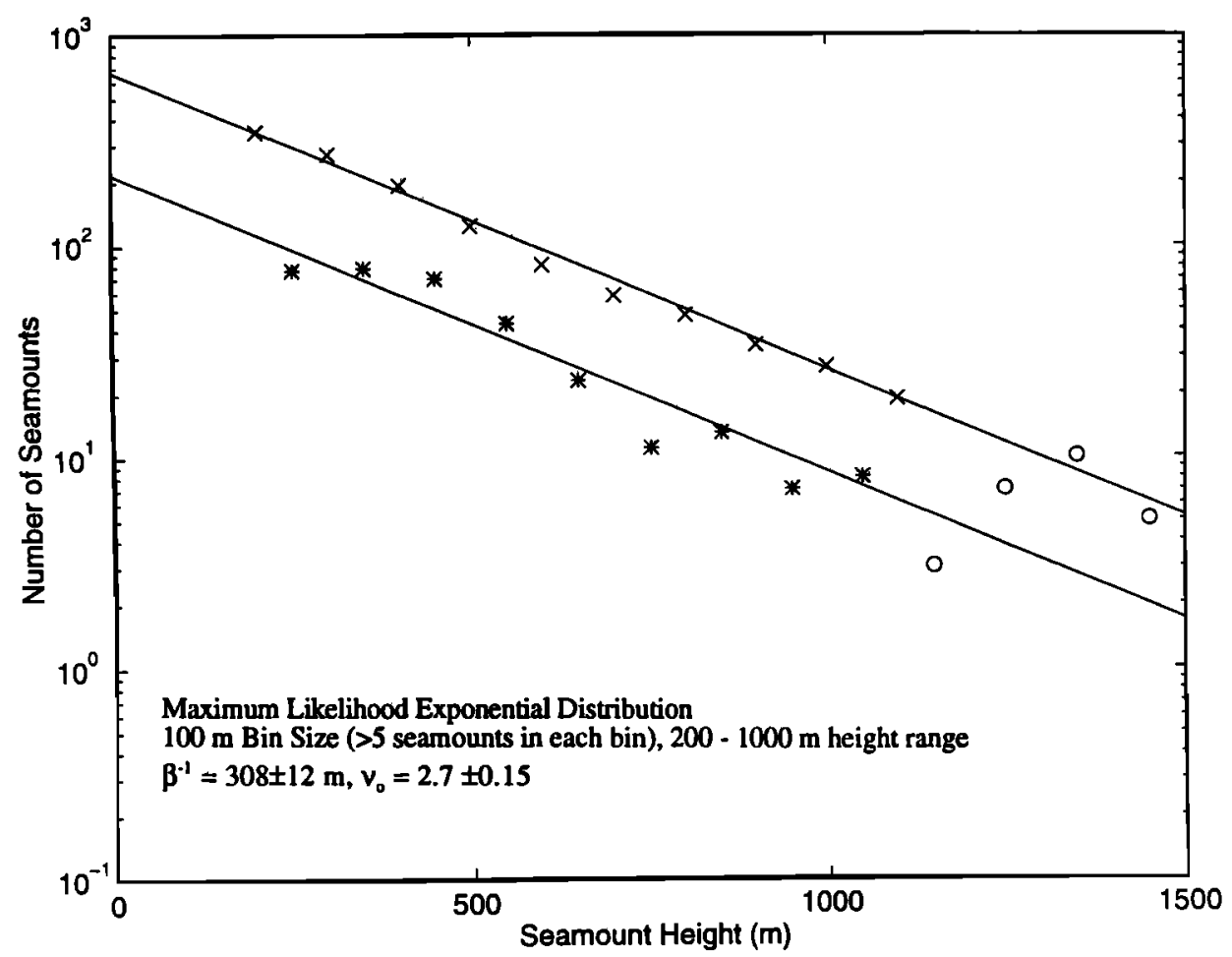

Figure 7. Exponential maximum-likelihood fit to ESC height data. Seamounts in $100 \mathrm{~m}$ height bins and greater than five seamounts in each bin. A total of 383 seamounts are observed with heights greater than 200 $\mathrm{m}$. The cumulative number of seamounts are plotted as crosses on the semi-log plot. Stars, raw frequency; crosses, cumulative frequency; and circles, raw frequency. The solid lines are the maximum likelihood fit to the raw and cumulative frequency counts, over the height ranging from $200-3300 \mathrm{~m}$ fit by the exponential model, $v(H)=v_{0} \exp (-\beta H)$. Where $v(H)$ for the cumulative number is the total expected number of seamounts over a given height $(H)$ in a given area, $v_{0}$ is the number of seamounts per unit area, $B^{-1}$ is the characteristic height of the population [Smith and Jordan, 1987]. Range of heights (given in meters), the minimum number in each bin, and the shape parameters $\left(\beta^{-1}\right.$ and $\left.v_{0}\right)$ are given.

whose age is greater than Chron $3(\sim 4 \mathrm{Ma})$ (Figure 3), or at a distance greater than $\sim 300 \mathrm{~km}$ from the axis. Additionally, the ages of the large seamounts are not much younger than the age of the seafloor upon which they lie, with age differences ranging from 3-8 Ma [Liu, 1996; O'Connor et al., 1995; $\mathrm{R}$. Duncan, personal communication, 1996]. Age differences between the seamount and seafloor decrease to the west, which implies that the locus of hotspot activity approaches the ridge over time. These ages are based on ${ }^{40} \mathrm{Ar} /{ }^{39} \mathrm{Ar}$ age measured on plagioclase, using an incremental heating method [ $O^{\prime}$ Connor et al., 1995; R. Duncan, personal communication, 1996]. Ages apparently increase from east to west along at least two dominant subparallel tracks, with trends $10^{\circ}-15^{\circ}$ clockwise relative to Nazca-hotspot motion [Liu, 1996]. Geochemical studies show an enriched plume signal influence in samples along the East Rift of the Easter microplate, with the strongest signal at $\sim 27^{\circ}$ S [e.g., Poreda et al., 1993a; Schilling et al., 1985a; Schilling, 1991]. Samples along the ESC show a pure plume signal, a pure MORB signal, or a mixture of the two side by side along the ESC [Haase and Devey, 1996; Haase et al., 1996; O'Connor et al., 1995]. Analysis of the effective elastic thickness ( $\mathrm{Te}$ ), provides an indication of the relative time of seamount loading, and shows timing to be uniform along the ESC and generally is low (Te $3 \mathrm{~km}$ ) [ $\mathrm{Liu}, 1996$; S.E. Kruse et al., Effective elastic thickness of the lithosphere along the Easter Seamount Chain, submitted to Journal of
Geophysical Research, 1997, hereinafter referred to as Kruse et al., submitted manuscript, 1997]. This suggests that the source of the volcanism has been relatively near the ridge axis for the past $9 \mathrm{Myr}$, partly due to repeated plate boundary reorganizations [Liu, 1996; Kruse et al., submitted manuscript, 1997].

The different models proposed for the formation of the ESC may be assessed from the findings of our study. Based on the location of the largest seamounts and their ages relative to the underlying seafloor, the largest seamounts could not have formed on the ridge-axis. Their location and age are consistent with a process occurring off-axis. The ESC study area has the following characteristics' (1) a uniform elastic thickness; (2) a gross scale age progression to the east, possibly along at least two subparallel tracks; and (3) at least two seamount populations, based on their size distribution. These observations cannot be accommodated by the models which predict simultaneous volcanism along the length of the chain, such as the "leaky fracture zone" [Clark and Dymond, 1977], "diffuse extension" [e.g., Sandwell et al., 1995], or "hot line" [Bonatti and Harrison, 1976]. The diffuse extension model predicts $\mathrm{N}-\mathrm{S}$ stress and thinning of the lithosphere, creating troughs along which minor upwelling would occur and seamount formation would be favored. There is no evidence of such topographic lows nor of ridge-parallel fissures. Secondary convection rolls, or "hot lines," predict 
Table 2. Comparison of Seamount Size Distribution Parameters With Other Studies

\begin{tabular}{|c|c|c|c|c|c|c|}
\hline Study & $\begin{array}{l}\text { Region } \\
\text { [Latitude] }\end{array}$ & $\begin{array}{l}\text { Height } \\
\text { Range, m }\end{array}$ & $\stackrel{v_{0}}{\stackrel{v_{0}}{\mathbf{k m}^{2}}}$ & $\begin{array}{l}B^{-1} \\
m\end{array}$ & $\begin{array}{l}\text { Mean } f \\
\text { [Range] }\end{array}$ & $\begin{array}{l}\text { Mean } \Phi \\
\text { [Range] }\end{array}$ \\
\hline This study & $\begin{array}{l}\mathrm{ESC} \\
{\left[27^{\circ}-29^{\circ} \mathrm{S}\right]}\end{array}$ & $200-1000$ & $2.7 \pm .15$ & 308 & $\begin{array}{l}0.15 \pm .1 \\
{[0-.57]}\end{array}$ & $\begin{array}{l}10 \pm 9.0 \\
{[2-32]}\end{array}$ \\
\hline $\begin{array}{l}\text { Scheirer et al. } \\
\text { [1996] }\end{array}$ & $\begin{array}{l}\text { southem EPR } \\
{\left[15^{\circ}-19^{\circ} \mathrm{S}\right]}\end{array}$ & $200-1200$ & $4.8 \pm 0.3$ & 421 & $\begin{array}{l}0.05 \pm .14^{a} \\
{[0-.76]}\end{array}$ & $\begin{array}{l}13 \pm 5.3^{a} \\
{[5-35]}\end{array}$ \\
\hline $\begin{array}{l}\text { Scheirer and } \\
\text { Macdonald } \\
\text { [1995] }\end{array}$ & $\begin{array}{l}\text { northern EPR } \\
{\left[8^{\circ}-18^{\circ} \mathrm{N}\right]}\end{array}$ & $200-800$ & $1.9 \pm 0.2$ & 240 & {$[0-0.6]$} & {$[5-25]$} \\
\hline $\begin{array}{l}\text { Abers et al. } \\
{[1988]^{\mathrm{b}}}\end{array}$ & $\begin{array}{l}\text { southern Pacific } \\
{\left[7^{\circ}-22^{\circ} \mathrm{S}\right]}\end{array}$ & $100-1000$ & $12.6 \pm 0.8$ & 174 & & \\
\hline $\begin{array}{l}\text { Abers et al. } \\
{[1988]^{\mathrm{c}}}\end{array}$ & southern Pacific & $100-600$ & $27.18 \pm 8.6$ & 68 & & \\
\hline $\begin{array}{l}\text { Bemis and Smith } \\
\text { [1993] }^{d}\end{array}$ & $\begin{array}{l}\text { southern. } \\
\text { Pacific } \\
{\left[9^{\circ}-22^{\circ} \mathrm{S}\right]}\end{array}$ & $300-700$ & $13 \pm 2$ & 233 & $\begin{array}{l}0.16 \pm .19 \\
{[0-.8]}\end{array}$ & \\
\hline $\begin{array}{l}\text { Smith and Jordan } \\
\text { [1987], and Smith } \\
\text { [1988] }\end{array}$ & $\begin{array}{l}\text { eastern } \\
\text { Pacific }^{c}\end{array}$ & $400-2500$ & $5.4 \pm 0.7$ & 285 & $\begin{array}{l}0.31 \pm .18 \\
{[0-.69]}\end{array}$ & $\begin{array}{l}18 \pm 6 \\
{[5-36]}\end{array}$ \\
\hline $\begin{array}{l}\text { Kleinrock and } \\
\text { Brooks [1994] }\end{array}$ & $\begin{array}{l}\text { Galapagos } \\
{\left[2^{\circ} \mathrm{N}, 95^{\circ} \mathrm{W}\right]}\end{array}$ & $50-350$ & $370 \pm 30$ & 29 & $\begin{array}{l}0.3 \pm .1 \\
{[0-.6]}\end{array}$ & $\begin{array}{l}13 \pm 4 \\
{[6-32]}\end{array}$ \\
\hline $\begin{array}{l}\text { Smith and Cann } \\
{[1990,1992]}\end{array}$ & $\begin{array}{l}\text { MAR } \\
{\left[24^{\circ}-30^{\circ} \mathrm{N}\right]}\end{array}$ & $50-210$ & $195 \pm 9$ & 58 & $\begin{array}{l}0.31 \pm .16 \\
{[0-.7]}\end{array}$ & $\begin{array}{l}15 \pm 4 \\
{[5-28]}\end{array}$ \\
\hline $\begin{array}{l}\text { Magde and Smith } \\
\text { [1995] }\end{array}$ & $\begin{array}{l}\text { northern MAR } \\
{\left[57^{\circ}-62^{\circ} \mathrm{N}\right]}\end{array}$ & $50-250$ & $310 \pm 20$ & 68 & $\begin{array}{l}0.46 \pm .2 \\
{[0-.9]}\end{array}$ & $23 \pm 6$ \\
\hline
\end{tabular}

Here

$B^{-1}$ is the characteristic height; $v_{0}$ is the total expected number; $f$ is the flatness; $\Phi$ is the slope: ESC is the Easter Seamount Chain; EPR is the East Pacific Rise; MAR is the Mid-Atlantic Ridge.

${ }^{\mathrm{a}}$ Calculated from published data.

${ }^{b}$ Whole region, 0-40 Ma.

'EPR region, 0-2 Ma.

${ }^{d}$ Wide beam data from EPR region.

'All regions except for hotspot areas.

volcanism along topographic highs, but this is not observed in the detailed bathymetry.

The geochemistry and shape distributions support a model which predicts interaction between an off-axis plume and material feeding the ridge axis [e.g., Fontignie and Schilling, 1991; Haase et al., 1996; O'Conner et al., 1995; Schilling et al., 1985a]. The seamount population consists of at least two types which we speculate have formed from magma having different physical properties; controlled in part by temperature, chemistry and crystal content of the source. A viscosity and/or effusion rate control might explain the differences in flatness and slope distributions. A hot source is expected to produce lower viscosity and higher effusion rate flows, and to form pointy seamounts with gentle slopes. The geochemical signal of the seamounts is expected to be that of ocean island basalt (OIB), a pure plume signal, if their magma source is decoupled from that of the ridge axis and surrounding mantle. However the results of geochemical studies describe a mixing between end members [e.g., Hanan and Schilling, 1989; Poreda et al., 1993b; Haase and Devey, 1996; Y. Pan and R. Batiza, Major element chemistry of volcanic glasses from the Easter Seamount Chain: Constraints on melting conditions in the plume channel, submitted to Journal of Geophysical Research, 1997]. Results of shape distribution analysis suggest that mixing among different sources is occurring over a regional scale. The spatial distribution of seamount shapes indicates that a simple rising plume is not responsible for the extensive volcanism. Rather, it seems that material is rising simultaneously at several locations, and this material has different chemical and physical properties, leading to differences in viscosity. Perhaps mixing of different material is occurring at shallow depth; thus lavas with a plume signature erupt close to others with a mixed source and on top of older seamounts formed by ridge axis processes [Haase et al., 1996]. The hybrid hotspot model of rising and shearing of miniplumes [Ihinger, 1995; Liu, 1996] explains the age data pattern along some of the ridge but lacks a satisfactory explanation for the formation of all the seamounts and their geochemical pattern. A high spreading rate may be responsible for the plume and nonplume mixing and subsequent complex seamount distribution pattern.

\section{Conclusions}

Based on the distribution of seamount shapes (slope and flatness), at least two seamount populations are identified in the study area: (1) Small volume volcanic edifices with variable flatness from small pointy cones to flattened domes and steep slopes; and (2) massive volcanic edifices with pointy summits and low slopes. The seamounts cover $\sim 27 \%$ of the seafloor and make up $4.3 \%$ of the total crustal volume. 
The few large seamounts contribute to the majority of the volcanic volume in the area: over $50 \%$ of the total volume of seamounts used in this study is made up by the 14 largest seamounts.

Observations made in this study, along with age and geochemical results of others, place constraints on the preferred model used to explain the formation of the ESC. Lithospheric stretching, secondary convection, and leaky fracture zone models may be ruled out because they predict contemporaneous ages along the entire length of the ridge, which is not observed in radiometric age data [ $O^{\prime} C o n n e r$ et al., 1995; Haase and Devey, 1996; Liu, 1996; R. Duncan, personal communication, 1996]. The lithospheric stretching model predict east-west fissures which are not observed in the bathymetry data. Instead geographically, wide-spread volcanism is observed, with at least two major, subparallel ridges. Based on previous work and our morphological study, we propose that the volcanoes are formed from more than one source. The lithospheric stretching, secondary convection (hotline), leaky fracture zone, and simple hotspot models do not satisfactorily explain the nonsystematic age progression from west to east nor the different types of seamounts which lie one beside another. The observations are better explained by a hotspot-ridge channel model with leaking to the seafloor [Haase et al., 1996; Schilling, 1991]. We speculate that the larger volcanoes $(>\sim 1200 \mathrm{~m}$ ) originate from only a hotspot source giving a more uniform morphology, whereas, only a portion of the smaller volcanoes $(<\sim 1200 \mathrm{~m})$ are formed from a hotspot source, each having a similar uniform morphology. The remainder would be presumably formed by a normal mantle or a mixed source, giving rise to a greater variability in the morphology observed.

Acknowledgments. We thank the shipboard scientists, R. Beale, D. Bishop, R. Hagen, A. Harris, C. Jacobs, J. Korenaga, R. Nelson, R. Rusby, H. Vergara, A. Woods, R. Batiza, D. Fontignie, R. Guarda, L. Joseph, C. Kincaid, R. Moe, T. Plake, R. Poreda, J.-G. Schilling, D. Sandwell, N. Seama, R. Stefani, and G. Wu. We thank Captain E. Buck and crew for their excellent ship handling and the government of Chile for permission to survey their waters. We also thank the people of Rapa Nui for their kind hospitality. We thank S. F. Tebbens, D. Scheirer, R. Batiza, D. K. Smith, D. L. Turcotte, J.-G. Schilling, and B. Malamud for useful discussions and suggestions and Martha G. Kuykendall for reviewing earlier versions. This paper benefited from the thorough reviews by J. Goff, D. Scheirer, and C. Small. Q. Lou typeset the manuscript. Most of the figures have been generated using GMT (Generic Mapping Tool) [Smith and Wessel, 1990; Wessel and Smith, 1991]. Funding was provided by NSF grants OCE9116012, OCE9214494, OCE9214495, OCE9214496, and OCE9302802.

\section{References}

Abers, G.A., B. Parsons, and J.K. Weissel, Seamount abundances and distributions in the southeast Pacific, Earth Planet. Sci. Lett., 87, 137$151,1988$.

Alexander, R.T., and K.C. Macdonald, Small off-axis volcanoes on the East Pacific Rise, Earth Planet. Sci. Lett., 139, 387-394, 1996.

Batiza, R., Abundances, distribution and sizes of volcanoes in the Pacific Ocean and implications for the origin of non-hotspot volcanoes, Earth Planet. Sci. Lett., 60, 195-206, 1982.

Batiza, R., Seamounts and seamount chains of the eastem Pacific, in The Geology of North America, vol. N, The Eastern Pacific Ocean and Hawaii, edited by E.L. Winterer, D.M. Hussong, and R.W. Decker, pp. 289-306, Geol. Soc. of Am., Boulder, Colo., 1989.

Batiza, R., and D. Vanko, Petrology of young Pacific seamounts, $J$. Geophys. Res., 89, 11,235-11,260, 1984.

Batiza, R., P.J. Fox, P.R. Vogt, S.C. Cande, N.R. Grindlay, W.G. Melson, and T. O'Hearn, Morphology, abundance, and chemistry of nearridge seamounts in the vicinity of the Mid-Atlantic Ridge $\sim 26^{\circ} \mathrm{S}, J$. Geol., 97, 209-220, 1989.
Bemis, K.G., and D.K. Smith, Production of small volcanoes in the Superswell region of the South Pacific, Earth Planet. Sci. Lett., 118, 251-262, 1993.

Binard, N., R. Hekinian, R.C. Searle, and P. Stoffers, Morphological and structural studies of the Society and Austral hotspots in the South Pacific, Tectonophysics, 186, 293-342, 1991.

Bonatti, E., and C.G.A. Harrison, Hot lines in the Earth's mantle, Nature, 263, 402-404, 1976.

Bonatti, E., and C.G.A. Harrison, Eruptive styles of basalts in oceanic spreading ridges and seamounts: Effect of magma temperature and viscosity, J. Geophys. Res., 93, 2967-2980, 1988.

Bonatti, E., C.G.A. Harrison, D.E. Fisher, J. Honnorez, J.G. Schilling, J.J. Stipp, and M. Zentilli, Easter volcanic chain (southeast Pacific): A mantle hot line, J. Geophys. Res., 82, 2457-2478, 1977.

Cande, S.C., and D.V. Kent, Revised calibration of the geomagnetic polarity timescale for the Late Cretaceous and Cenozoic, $J$. Geophys. Res., 100, 6093-6095, 1995.

Chen, Y., and J. Morgan, A nonlinear rheology model for mid-ocean ridge axis topography, J. Geophys. Res., 95, 17,583-17,604, 1990.

Chen, Y.J., Oceanic crustal thickness versus spreading rate, Geophys. Res. Lett., 19(8), 753-756, 1992.

Clark, J.G., and J. Dymond, Geochronology and petrochemistry of Easter and Sala y Gomez Islands: Implications for the origin of the Sala y Gomez Ridge, J. Volcanol. Geotherm. Res., 2, 29-48, 1977.

Danobeitia, J.J., et al., Geophysical study along the Easter-Salas y Gomez volcanic ridge (southeast Pacific), InterRidge News, 4(1), 19 22, 1995 .

Davis, E.E., and J.L. Karsten, On the cause of asymetric distribution of seamounts about the Juan de Fuca ridge: ridge-crest migration over a heterogeneous asthenosphere, Earth Planet. Sci. Lett., 79, 385-296, 1986.

DeMets, C., R.G. Gordon, D.F. Argus, and S. Stein, Current plate motions, Geophys. J. Int., 101, 425-478, 1990.

DeMets, C., R. Gordon, D.F. Argus, and S. Stein, Effects of recent revisions to the geomagnetic reversal time scale on estimates of current plate motions, Geophys. Res. Lett., 2I(20), 2191-2194, 1994.

Duncan, R.A., and M.A. Richards, Hotspots, mantle plumes, flood basalts, and true polar wander, Rev. Geophys., 29(1), 31-50, 1991.

Epp, D., Possible perturbations to hotspot traces and implications for the origin and structure of the Line Islands, J. Geophys. Res., 89, 11,273$11,286,1984$.

Fontignie, D., and J.-G. Schilling, Sr (87/86) and REE variations along the Easter microplate boundaries (South Pacific): Application of multivariate statistical analyses to ridge segmentation, Chem. Geol., 89, 209-241, 1991.

Fornari, D.J., R. Batiza, and J.F. Allan, Irregularly shaped seamounts near the East Pacific Rise: Implication for seamount origin and rise axis processes, in Seamounts, Islands, and Atolls, Geophys. Monogr. Ser., vol. 43, edited by B.H. Keating et al., pp. 35-48, AGU, Washington, D. C., 1987a.

Fornari, D.J., R. Batiza, and M.A. Luckman, Seamount abundances and distribution near the East Pacific Rise $0^{\circ}-24^{\circ}$ based on Seabeam data, in Seamounts, Islands, and Atolls, Geophys. Monogr. Ser., vol. 43, edited by B.H. Keating et al., pp. 13-21, AGU, Washington, D. C., $1987 \mathrm{~b}$.

Fornari, D.J., M.R. Perfit, J.F. Allan, R. Batiza, R. Haymon, A. Barone, W.B.F. Ryan, T Smith, T. Simkin, and M.A. Luckman, Geochemical and structural studies of the Lamont seamounts: Seamounts as indicators of mantle processes, Earth Planet. Sci. Lett., 89, 63-83, 1988.

Gripp, A.E., Current plate motions: reference frames and uncertainties Ph.D. dissertation, Northwestern Univ., Evanston, Ill., 1994.

Haase, K.M., and C.W. Devey, Geochemistry of lavas from the Ahu and Tupa volcanic fields, Easter hotspot, southeast Pacific: Implications for intraplate magma genesis near a spreading axis, Earth Planet. Sci. Lett., 137, 129-143, 1996.

Haase, K.M., S.L. Goldstein, C.W. Devey, P. Stoffers, and C.-D. GarbeSchoneberg, Ridge-hotspot interaction between Easter Island and the Easter microplate spreading area, Eos Trans. $A G U, 74(43)$, Fall Meet Supp., 673, 1993.

Haase, K.M., C.W. Devey, and S.L. Goldstein, Two-way exchange between the Easter mantle plume and the Easter microplate spreading axis, Nature, 383, 344-346, 1996.

Hagen, R.A., N.A. Baker, D.F. Naar, and R.N. Hey, A SeaMARC II survey of recent submarine volcanism near Easter Island, Mar. Geophys. Res., 12, 297-315, 1990.

Hanan, B.B., and J.-G. Schilling, Easter microplate evolution: $\mathrm{Pb}$ isotope evidence, J. Geophys. Res., 94, 7432-7448, 1989. 
Hey, R.N., P.D. Johnson, F. Martinez, J. Korenaga, M.L. Somers, Q.J. Huggettt, T.P. LeBas, R.I. Rusby, and D.F. Naar, Plate boundary reorganization at a large-offset, rapidly propagating rift, Nature, 378 , 167-170, 1995.

Holcomb, R.T., and R.C. Searle, Large landslides from oceanic volcanoes, Mar. Geotechnol., 10, 19-32, 1991.

Ihinger, P.D, Mantle flow beneath the Pacific Plate: Evidence from seamount segments in the Hawaiian-Emperor Chain, Am. J. Sci., $295,1035-1057,1995$.

Jackson, E.D., and H.R. Shaw, Stress field in central portions of the Pacific plate: Delineated in time by linear volcanic chains, $J$. Geophys. Res., 80, 1861-1875, 1975.

Jordan, T.H., W. Menard, and D.K. Smith, Density and size distribution of seamounts in the eastern Pacific inferred from wide-beam sounding data, J. Geophys. Res., 88, 10,508-10,518, 1983.

Karsten, J.L., and J.R. Delaney, Hot spot-ridge crest convergence in the northeast Pacific, J. Geophys. Res., 94, 700-712, 1989.

Kincaid, C., J.-G. Schilling, and C. Gable, The dynamics of off-axis plume-ridge interaction in the uppermost mantle, Earth Planet. Sci. Lett., 137, 29-43, 1996.

Kleinrock, M.C., and B.A. Brooks, Construction and destruction of volcanic knobs at the Cocos-Nazca spreading system near $95^{\circ} \mathrm{W}$, Geophys. Res. Lett., 21(21), 2307-2310, 1994.

Liu, Z.J., The origin and evolution of the Easter Seamount Chain, Ph.D. dissertation, Univ. of South Fla., St. Petersburg, 1996.

Liu, Z.J., Y. Rappaport, and D.F. Naar, GLORI-B side-scan swath bathymetry along the Easter Seamount Chain, Eos Trans. AGU, 74(43), Fall Meet. Suppl., 688, 1993.

Liu, Z.J., D.F. Naar, R. Beale, M. Somers, and C. Demoustier, GLORI-B data processing, Eos Trans. $A G U, 75(16)$, Spring Meet. Suppl., 341, 1994.

Macdonald, K., The crest of the Mid-Atlantic Ridge: Models for crustal generation processes and tectonics, in The Geology of North America, vol. M, The Western North Atlantic Region, edited by P.R. Vogt and B.E. Tucholke, pp. 51-68, Geol. Soc. of Am., Boulder, Colo. 1986.

Macdonald, K., D. Scheirer, and D. Forsyth, Contrasting styles of nearaxis seamount volcanism near the southern and northern East Pacific Rise, Eos Trans. AGU, 74 (43), Fall Meet. Suppl., 687, 1993.

Magde, L.S., and D.K. Smith. Seamount volcanism at the Reykjans Ridge: relationship to the Iceland hot spot, J. Geophys. Res., 100, 8449-8468, 1995.

Maia, M., G.A. Dehghani, J. Francheteau, and P. Stoffers, Gravity study of the Pitcairn-Easter hotline, Geophys. Res. Lett., 2I(23), 2527 2530, 1994.

McNutt, M., S. Fischer, S. Kruse, and J. Natland, The origin of the Marquesas fracture zone ridge and its implication for the nature of hot spots, Earth Planet. Sci. Lett., 91, 381-393, 1989

Menard, H.W., Marine Geology of the Pacific, McGraw-Hill, New York, 1964

Moore, J.G., D.A. Clague, R.T. Holcomb, P.W. Lipman, W.R. Normark and M.E. Toressan, Prodigious submarine landslides on the Hawaiin Ridge, J. Geophys. Res., 94, 17,465-17,484, 1989.

Morgan, W.J., Convection plumes in the lower mantle, Nature, 230, $197-$ 198, 1971.

Morgan, W.J., Plate motions and deep mantle convection, Mem. Geol. Soc. Am., 132, 7-22, 1972.

Naar, D.F., and R.N. Hey, Recent Pacific-Easter-Nazca plate motions, in Evolution of Mid Ocean Ridges, Geophys. Monogr. Ser., vol. 57, edited by J.M. Sinton, pp. 9-30, AGU, Washington, D.C., 1989.

Naar, D.F., R. Batiza, R. Poreda, and J.-G. Schilling, Final cruise report for the R/V Melville GLORIA expedition Legs 6 and 7, Univ. of South Fla., St. Petersburg, 1993a.

Naar, D.F., et al., GLORI-B and geochemical investigation of the Easter Seamount Chain: EPR to San Ambrosio Island, Eos Trans. $A G U, 74(43)$, Fall Meet. Suppl., 672, $1993 \mathrm{~b}$.

O'Conner, J.M., P. Stoffers, and M.O. Mcwilliams, Time-space mapping of Easter Chain volcanism, Earth Planet. Sci. Lett., 136, 197-212, 1995.

Okal, E.A., and A. Cazenave, A model for the plate tectonic evolution of the east-central Pacific based on SEASAT investigations, Earth Planet. Sci. Lett., 72, 99-116, 1985.

Olson, P., and I.S. Nam, Formation of seafloor swells by mantle plumes, J. Geophys. Res., 91, 7181-7191, 1986.

Pilger, R.H., Jr., and D.W. Handschumacher, The fixed-hotspot hypothesis and the origin of the Easter-Sala y Gomez-Nazca trace, Geol. Soc. Am. Bull., 92 (Part I), 437-446, 1981.

Poreda, R.J., J.-G. Schilling, R. Batiza, and D. Naar, Geochemistry of volcanism along the Easter Seamount Chain, Eos Trans. $A G U, 74$ (43), Fall Meet. Suppl., 672, 1993a.

Poreda, R.J., J.-G. Schilling, and H. Craig, Helium isotope ratios in Easter microplate basalts, Earth Planet. Sci. Lett., 119, 319-329, 1993b.

Rappaport, Y., Seamount size and shape distribution near Easter Island, M.S. thesis, Univ. of South Fla., St. Petersburg, 1996.

Rappaport, Y., Z.J. Liu, and D.F. Naar, Seamount abundances and distribution near Easter Island from GLORI-B swath bathymetry, Eos Trans. AGU, 75 (44), Fall Meet. Suppl., 582, 1994.

Richter, F.M., and B. Parsons, The interaction of two scales of convection in the mantle, J. Geophys. Res., 80, 2529-2541, 1975.

Sandwell, D.T., E.L. Winterer, J. Mammerickx, R.A. Duncan, M.A. Lynch, D.A. Levitt, and C.L. Johnson, Evidence for diffuse extension of the Pacific plate from Pukapuka ridges and cross-grain gravity lineations, J. Geophys. Res., 100, 15,087-15,099, 1995.

Scheirer, D.S., and K.C. Macdonald, Near-axis seamounts on the flanks of the East Pacific Rise, $8^{\circ} \mathrm{N}$ to $17^{\circ} \mathrm{N}, J$. Geophys. Res., 100, 2239 . 2259,1995

Scheirer, D.S., K.C. Macdonald, D.W. Forsyth, and Y. Shen, Abundant seamounts of the Rano Rahi seamount field near the southern East Pacific Rise, $15^{\circ} \mathrm{S}$ to $19^{\circ} \mathrm{S}$, Mar. Geophys. Res., 18, 13-52, 1996.

Schilling, J.-G., Upper mantle heterogeneities and dynamics, Nature $314,62-67,1985$

Schilling, J.-G., Fluxes and excess temperature of mantle plumes inferred from their interaction with migrating mid-ocean ridges, Nature, 352, 397-403, 1991.

Schilling, J.-G., H. Sigurdsson, A.N. Davis, and R.N. Hey, Easter microplate evolution, Nature, 317, 325-331, 1985a.

Schilling, J.G., G. Thompson, R. Kingsley, and S. Humphris, Hotspotmigrating ridge interaction in the South Atlantic, Nature, 313, 187$191,1985 \mathrm{~b}$.

Searle, R., Submarine central volcanoes on the Nazca plate-High resolution sonar observations, Mar. Geol., 53, 77-102, 1983.

Searle, R.C., J. Francheteau, and B. Cornaglia, New observations on mid-plate volcanism and the tectonic history of the Pacific plate, Tahiti to Easter microplate, Earth Planet. Sci. Lett., 131, 395-421, 1995.

Shen, Y., D.W. Forsyth, D.S. Scheirer, and K.C. Macdonald, Two forms of volcanisms: Implications for mantle flow and off-axis crustal production on the west flank of the southern East Pacific Rise, $J$. Geophys. Res., 98, 17,875-17,889, 1993.

Shen, Y., D.S. Scheirer, D.W. Forsyth, and K.C. Macdonald, Trade-off in production between adjacent seamount chains near the East Pacific Rise, Nature, 373, 140-143, 1995.

Smith, D.K., Shape analysis of Pacific seamounts, Earth Planet. Sci. Lett., 90, 457-466, 1988.

Smith, D.K., and J.R. Cann, Hundreds of small volcanoes on the median valley floor of the Mid-Atlantic Ridge at $24-30^{\circ} \mathrm{N}$, Nature, 348,152 155, 1990.

Smith, D.K., and J.R. Cann, The role of seamount volcanism in crustal construction at the Mid-Atlantic Ridge $\left(24^{\circ}-30^{\circ} \mathrm{N}\right), J$. Geophys. Res. 97, 1645-1658, 1992.

Smith, D.K., and J.R. Cann, Building the crust at the Mid-Atlantic Ridge, Nature, 365, 707-715, 1993.

Smith, D.K., and T.H. Jordan, The size distribution of Pacific seamounts, Geophys. Res, Lett., 14(11), 1119-1122, 1987.

Smith, D., K., and T.H. Jordan, Seamount statistics in the Pacific Ocean, J. Geophys. Res., 93(B4), 2899-2918, 1988.

Smith, W.H.F., and P. Wessel, Gridding with continuous curvature splines in tension, Geophysics, 55, 293-305, 1990.

Smoot, C.N., and R.E. King, Three-dimensional secondary surface geomorphology of submarine landslides on northwest Pacific plate guyots, Geomorphology, 6, 151-174, 1992.

Somers, M.L., and D.Q.J. Huggett, From GLORIA to GLORI-B: New upgrades add swath bathymetry to 20-year-old GLORIA reconnaissance sonar images, Sea Technol., 34(6), 6468, 1993.

Stoffers, A., et al., Geology of young submarine volcanoes west of Easter Island, Southeast Pacific, Mar. Geol., 118, 177-185, 1994.

Turcotte, D.L., and E.R. Oxburgh, Intra-plate volcanism, Philos. Trans. $R$. Soc. of London, Ser., 288, 561-579, 1978.

Vogt, P.R., Volcano height and plate thickness, Earth Planet. Sci. Lett., 23, 337, 1974.

Vogt, P.R., and C.N. Smoot, The Geisha guyots: Multibeam bathymetry and morphometric interpretation, J. Geophys. Res., 89, 11,085$11,107,1984$.

Wessel, P., and W.H. Smith, Free software helps map and display data, Eos Trans. AGU, 72, 441, 445-446, 1991. 
Wilson, J.T., Evidence from islands on the spreading of ocean floors, Nature, 197, 536-538, 1963a.

Wilson, J.T., A possible origin of the Hawaiian Islands, Can. J. Phys., 41, 863-870, $1963 \mathrm{~b}$.

Wilson, L., J.W. Head, and E.A. Parfit, The relationship between the height of a volcano and the depth to its magma source zone: A critical reexamination, Geophys. Res. Lett., 19(13), 1395-1398, 1992.

Winterer, E.L., and D.T. Sandwell, Evidence from en-echelon crossgrain ridges for tensional cracks in the Pacific plate, Nature, 329, 534-537, 1987.

C. C. Barton, U. S. Geological Survey, 600 4th St. S., St. Petersburg, FL 33701. (email: barton@bpgsvr.cr.usgs.gov)
R. N. Hey, SOEST, University of Hawaii, 2525 Correa Rd., Honolulu, HI 96822. (email: hey@soest.hawaii.edu)

Z. J. Liu, Department of Geophysics and Computer Science, Stanford University, Stanford, CA 94305. (email: zjl@cs.stanford.edu)

D. F. Naar, Department of Marine Science, University of South Florida, 140 7th Ave. S., St. Petersburg, FL 33701-5016. (email: naar@marine.usf.edu)

Y. Rappaport, Infrastructure Support Services, City of Austin, 301 West 2nd Street, Austin, TX 78701. (email: yrappaport@maxvax.ci.austin.tx.us)

(Received July 15, 1996; revised May 30, 1997; accepted June 3, 1997.) 